\title{
Labor Laws and Innovation
}

\author{
Viral V. Acharya New York University \\ Ramin P. Baghai Stockholm School of Economics \\ Krishnamurthy V. Subramanian Indian School of Business
}

\begin{abstract}
When contracts are incomplete, dismissal laws prevent employers from arbitrarily discharging employees and thereby limit employers' ability to hold up innovating employees after an innovation is successful. Therefore, dismissal laws can enhance employees' innovative efforts and encourage firms to invest in risky but potentially groundbreaking projects. Other forms of labor laws that do not affect dismissal of employees do not have this bright side. We find support for these predictions in empirical tests that exploit country-level changes in dismissal laws in the United States, the United Kingdom, France, and Germany: more stringent dismissal laws foster innovation, particularly in innovation-intensive industries, but other labor laws do not.
\end{abstract}

\section{Introduction}

Do the legal institutions of an economy affect the pattern of its real investments and, in turn, its economic growth? In this paper, we focus on one specific aspect of this overarching theme. In particular, we investigate whether the legal framework governing the relationships between employees and their employers affects the extent of innovation in an economy.

We are grateful to Sam Peltzman (the editor), an anonymous referee, Amit Seru, and Vikrant Vig for valuable comments and suggestions. We would like to thank Anusha Chari, Rich Mathews, Amalia R. Miller, and Radha Iyengar for their insightful discussions. Furthermore, we would like to thank seminar and conference participants at the American Law and Economics annual meeting (University of San Diego School of Law, May 15-16, 2009), the Western Finance Association annual meeting (San Diego, June 17-20, 2009), the National Bureau of Economic Research Summer Institute meetings Innovation Policy and the Economy (Cambridge, Massachusetts, July 20, 2009) and Law and Economics (Cambridge, Massachusetts, July 22-23, 2009), the Summer Research Conference in Finance at the Indian School of Business (Hyderabad, July 16-19, 2009), Cambridge University Centre for Business Research, Emory University, London Business School, New York University (NYU) microeconomics seminar, and NYU-Stern School of Business for valuable comments and suggestions. We thank Hanh Le and Chandrasekhar Mangipudi for excellent research assistance. 
While the inefficiencies and rigidities associated with stringent labor lawslaws that prevent employers from seamlessly negotiating and/or terminating labor contracts with employees - are much discussed in the academic literature ${ }^{1}$ and the media, this discussion is generally centered around the ex post effects of labor laws. ${ }^{2}$ In particular, it is clear that once the opportunity to renegotiate or terminate an employment contract has arisen, preventing an employer from doing so can lead to ex post inefficient outcomes. Much less studied, however, is the ex ante incentive effect of such strong labor laws. Might stringent labor laws - even if as an unintended consequence-provide firms with a commitment device to not punish short-run failures and to not hold up their employees in case of successful innovations, thereby spurring employees to undertake activities that are value maximizing in the long run?

This question assumes importance on two counts. First, as highlighted by the literature on endogenous growth (Romer 1990; Grossman and Helpman 1991; Aghion and Howitt 1992), innovative investments spur technological progress in a country and are, therefore, an essential ingredient of economic growth. This theory stresses the role of laws and institutions that nurture innovation and, thereby, generate positive externalities that can permanently raise a country's long-run growth rate. Second, recent evidence suggests that wrongful-discharge laws-that is, laws that prevent firms from arbitrarily discharging employeespassed by U.S. states encourage innovation and new-firm creation (Acharya, Baghai, and Subramanian 2014).

Laws that impose hurdles on dismissal capture only one particular form of restriction on the employer-employee relationship. Labor laws, however, affect many other aspects of the employer-employee relationship and, therefore, exhibit considerable variety. For example, one important category of labor laws impacts workers' ability to unionize, while another one governs workers' rights to engage in militant action in the form of strikes. In this paper, we ask whether the positive effect of labor laws on innovation is restricted to laws that inhibit dismissal or whether it is the case that any restriction placed on the employer-employee relationship secularly encourages innovation. We find that only dismissal laws have an ex ante positive incentive effect by encouraging firms and their employees to engage in more successful, and more significant, innovative pursuits. Other forms of labor laws do not generate such ex ante positive incentive effects on innovation. We provide this evidence using country-level changes in dismissal laws from 1970 to 2002 for four countries: the United States, the United Kingdom, France, and Germany.

Because innovation involves considerable exploration, the difficulty in describing innovative activities ex ante, combined with the possibility of ex post

\footnotetext{
${ }^{1}$ Botero et al. (2004), for example, argue that heavier regulation of labor leads to adverse consequences for labor market participation and unemployment.

${ }^{2}$ For example, strong labor market regulation is often blamed as one of the reasons for Europe's economic underperformance, compared with the United States. For research articulating this theme, see the study of France and Germany by the McKinsey Global Institute (1997).
} 
renegotiation, makes it difficult to write complete contracts in innovative settings (Aghion and Tirole 1994). Therefore, to appropriate a larger share of the substantial payoff from successful innovation, innovative firms may hold up, that is, fire employees who contributed to such an innovation. In fact, a recent highprofile court case filed against the video game company Activision by former employees Jason West and Vince Zampella highlights such possible holdup. ${ }^{3}$ Dismissal laws can help to limit the occurrence of holdup and thereby increase the employee's innovative effort. This theoretical argument, which is formalized in Acharya, Baghai, and Subramanian (2014), leads to the following empirical predictions:

Hypothesis 1. Stronger dismissal laws lead to greater innovation.

Because the ex ante incentive effect should matter more in the innovative sectors, we test

Hypothesis 2. Stronger dismissal laws lead to relatively more innovation in the innovation-intensive industries than in traditional industries.

Because other aspects of labor laws do not have this ex ante incentive effect, we also test

Hypothesis 3. Labor laws other than those governing dismissal of employees do not result in a positive effect on innovation.

We provide evidence supporting the hypotheses by exploiting changes in dismissal laws at the country level. We employ data on patents issued by the U.S. Patent and Trademark Office (USPTO) to U.S. and foreign firms, as well as citations to these patents, as constructed by Hall, Jaffe, and Trajtenberg (2001). We measure innovation using the number of patents applied for (and subsequently granted), the number of all subsequent citations to these patents, and, as our theoretical motivation implies more risk taking subsequent to the passage of stronger dismissal laws, the standard deviation of citations. As our primary explanatory variable, we employ an index of dismissal laws developed by Deakin, Lele, and Siems (2007). They construct this index by analyzing in detail every legal change pertaining to dismissal of employees in five countries-the United States, the United Kingdom, France, Germany, and India-over the period 19702006. The index takes into account not just the formal or positive law but also the self-regulatory mechanisms that play a functionally similar role to laws in certain countries. While using the Deakin, Lele, and Siems (2007) index forces us to focus our analysis on five countries, these countries account for about 70 percent of the patents filed with the USPTO during our sample period. ${ }^{4}$

We conduct our tests at two levels of aggregation: the country level, where

\footnotetext{
${ }^{3}$ The lawsuit alleges that Activision fired West and Zampella after they completed the video game development and before they received the royalties for their work. For details, see Reilly (2010).

${ }^{4}$ Because of very limited patenting with the U.S. Patent and Trademark Office, we exclude India from our tests. However, all results remain robust to the inclusion of India in the sample.
} 
we exploit only variation in innovation across time within a country, and the industry level, where we exploit variation both across time and within different industries of a country. The industry-level classification that we employ is very granular and corresponds to around 500 patent classes that the USPTO defines. To test hypothesis 1, we first examine the correlation between our innovation proxies in a given country and year and dismissal laws in a given country in the previous year and in the 2 previous years. In estimating this correlation, we control for unobserved heterogeneity at the country level (through country fixed effects), secular time trends and macrolevel effects (through year dummies), and several country- and industry-level variables. The presence of the country and year fixed effects enables us to estimate this correlation as a difference in differences, that is, the before-after difference in innovation in a country and year in which there was a change in dismissal laws vis-à-vis the before-after difference in a country and year where there was no such change. We find that more stringent dismissal laws in a particular year are positively correlated with subsequent innovation.

As a specific source of endogeneity, changes in a country's government (that is, changes in its political leanings) may confound our results, as could the correlation of changes in dismissal law with economic growth and periods of business cycle contractions. To directly control for these sources of endogeneity in the difference-in-differences tests, we rerun our basic panel regressions after including a time-varying proxy for the political leanings of a country's government; the gross domestic product (GDP) growth rate, to control for economic growth; and country-specific periods of business cycle contractions. We find that the effect of dismissal laws on innovation remains robust.

Despite controlling for an exhaustive set of observable variables that may influence innovation and the passage of dismissal laws, we are careful not to ascribe a causal interpretation to the above correlation since the possibility remains that unobserved factors accompanying law changes may lead to the correlation. As the centerpiece of our identification strategy, we undertake tripledifference tests in which we absorb all variation at the country-year level through country $\times$ year fixed effects and identify the effect of dismissal laws on innovation within industries in a country. This identification strategy is motivated by hypothesis 2 , which predicts that the effect of dismissal laws should be disproportionately stronger in industries that exhibit a greater propensity to innovate than in other industries. To conduct these tests, we employ two proxies for an industry's innovation intensity. First, we use the National Science Foundation's measure of the number of research and development (R\&D) scientists and engineers employed per thousand employees in an industry in the United States. Second, using firm-level data from the United States, we obtain the median ratio of $R \& D$ expenditure to assets ( $R \& D /$ Assets) in an industry in a given year. By interacting these proxies with the dismissal law index, we find that the coefficient on this interaction term is significantly positive, which implies that the effect of dismissal laws is more pronounced in industries that have a greater 
propensity to innovate. These tests serve two important purposes. First, they highlight the channel for the main effect-the industry's propensity to innovate. Second, they ensure that neither changes in a country's government nor economic growth, country-specific business cycles, or any other country-level variable that correlates with changes in dismissal law accounts for our findings.

Having controlled for all possible omitted variables at the country level, we then undertake triple-difference tests that account for possible placebo effects at the country and industry level. The hypothesized effect of dismissal laws on innovation stems from the increased effort by a firm's employees due to the reduced possibility of holdup. Since individual inventors are not employed by a firm, this predicted effect of dismissal laws should not manifest for innovation by individual inventors. However, individual inventions may be affected by other, possibly omitted, country- and industry-level variables in a fashion similar to innovation by firms. Therefore, stand-alone inventors provide a control group whose innovative output should not be affected by changes in dismissal laws. Hence, we employ innovation by firms minus innovation by individual inventors as the dependent variable to net out any confounding effects driven by omitted variables at the country and industry level. Reassuringly, our results continue to hold. Both sets of triple-difference tests together provide evidence of the causal effect of dismissal laws on innovation.

Finally, we shed light on hypothesis 3. Deakin, Lele, and Siems (2007) not only construct a dismissal law index but also generate indices to measure other dimensions of labor laws (for example, laws governing industrial action or employee representation). This enables us to study the effect of these other dimensions of labor laws on innovation. We find that dismissal laws are the only aspect of labor law that has a consistently positive and significant effect on innovation.

In other tests, we confirm that the direction of causality runs from dismissal laws to innovation rather than vice versa. Further, we show that our results are not driven by physical capital deepening, that is, labor substitution as a response to the strengthening of dismissal laws: the concern is that more stringent dismissal laws could hasten the adoption of more innovative, laborsaving technologies instead of providing stronger incentives for innovation. However, we do not find a significant association of dismissal laws with either firm-level R\&D or capital expenditure.

In summary, we conclude that stronger dismissal laws encourage innovation. The effect is economically significant. Since we identify the intended effects using specific law changes, consider a typical law change as an example. The United Kingdom increased the procedural hurdles relating to dismissal of employees in 1987, which increased the dismissal law index by .0378. Using our coefficient estimates from the country-level tests, we find that this change in law increased the annual number of patents, number of citations, and standard deviation of citations by 1.3 percent, 1.6 percent, and 2.2 percent, respectively.

The cross-country tests complement the findings of Acharya, Baghai, and 
Subramanian (2014), who show that the staggered adoption of common-law exceptions to the employment-at-will principle (so-called wrongful-discharge laws) in several U.S. states resulted in more innovation and entrepreneurship by U.S. firms. Apart from the different setting (cross-country law changes and tests vis-à-vis changes in U.S. state law), the present study differs from that of Acharya, Baghai, and Subramanian (2014) in other key ways. First, since the cross-country setting provides variation stemming from the passage of other labor laws as well, we are able to confirm here that dismissal laws are salient in engendering positive incentives for innovation, while other dimensions of labor laws do not have this salutary effect. Second, since our cross-country tests exploit country-level changes in dismissal laws, these time-series tests provide point estimates of the effect of changes in dismissal laws on innovation using experiments of greatest relevance to country-level policies concerned with promoting innovation.

The rest of the paper is organized as follows. Section 2 places our study relative to the extant literature. Section 3 discusses the political economy of dismissal laws. Section 4 presents the theoretical motivation. Section 5 discusses the main data and proxies used in our tests. Section 6 describes the empirical results. Finally, Section 7 concludes.

\section{Related Literature}

Our study complements the findings in Acharya, Baghai, and Subramanian (2014), who show that the staggered adoption of common-law exceptions to the employment-at-will principle (so-called wrongful-discharge laws) in several U.S. states resulted in more innovation by U.S. firms. Our paper also contributes to the body of literature that examines the effect of laws governing the employeremployee relationship (for example, Botero et al. 2004; Besley and Burgess 2004; Atanassov and Kim 2009; Bassanini, Nunziata, and Venn 2009). In contrast to these studies that document the negative effects of labor laws, our study finds that some types of stringent labor laws can motivate a firm and its employees to pursue value-enhancing innovative activities. Our study resembles that of Menezes-Filho and Van Reenen (2003) in documenting some positive effects of labor laws. However, while Menezes-Filho and Van Reenen (2003) focus on laws governing unions, we examine all dimensions of labor laws and pay particular attention to laws governing the dismissal of employees.

Our study relates to that of MacLeod and Nakavachara (2007), who develop a theoretical model and provide empirical evidence that the passage of wrongfuldischarge laws across several U.S. states enhances (reduces) employment in industries requiring high (low) relationship-specific investment. Garmaise (2011) uses legal enforcement of employee noncompete agreements (NCAs) across U.S. states as a proxy for laws that limit human capital mobility and finds that such laws enhance executive stability. Lavetti, Simon, and White (2012) argue that NCAs can reduce investment holdups and increase productive efficiency. Using 
survey data, they find that physicians with NCAs have stronger incentive contracts, are more productive, earn higher wages, and have higher within-job earnings growth. Noncompete agreements also increase returns to both tenure and experience, which suggests that they promote general as well as firm-specific human capital investment. Saint-Paul (2002b) argues theoretically that employment protection may alter the pattern of specialization in favor of low-risk, mature goods and secondary innovation, which is focused on improving existing products rather than creating new ones. Lerner and Wulf (2007) report that long-term incentives provided to corporate R\&D heads of publicly listed U.S. firms are associated with greater firm-level innovation. Finally, Chemmanur and Tian (2013) show that firms with more antitakeover provisions are more innovative, as these provisions insulate managers from short-term pressures arising from the equity market.

Our paper also relates to recent studies showing that laws and contracts that exhibit tolerance to failure can be instrumental in fostering innovation and economic growth. Acharya and Subramanian (2009) report that the ex post inefficient continuations engendered by debtor-friendly bankruptcy laws encourage ex ante risk taking and thereby promote firm-level innovation and country-level economic growth. Manso (2011) shows theoretically that the optimal contract to motivate innovation not only exhibits tolerance for short-term failure but also, in fact, rewards interim failure to create the incentives for successful innovation in the long term; Ederer and Manso (2013) find evidence supporting this thesis. Tian and Wang (2014) show that tolerance for failure among venture capitalists spurs innovation in their portfolio firms.

\section{The Political Economy of Labor Market (De-)Regulation}

Labor laws-labor market regulation that enhances employees' bargaining power vis-à-vis employers_can take two forms (see Deakin, Lele, and Siems 2007): formal or positive law, or regulatory mechanisms that are functionally equivalent to formal laws (such as collective agreements). Such labor market regulation is often driven by political considerations: countries with a longer history of left-leaning governments tend to have more stringent labor regulation (Botero et al. 2004). Consistent with such an association, Deakin, Lele, and Siems (2007) also document that the primary motivation for labor market (de-)regulation is political. For example, they find that a considerable decrease in the intensity of labor market regulation in the United Kingdom during the 1980s and early 1990s coincided with the election of a Conservative government committed to labor market deregulation. Similarly, they report that a limited renaissance of the regulation of labor markets in the United Kingdom was triggered by the return to office in 1997 of a Labour Party government, which also ended the United Kingdom's opting out of the European Social Charter. In France, the election of a Socialist Party government in 1981 led to a series of labor law reforms aimed at shifting the balance of power toward employees: the Auroux 
laws. These laws, which were enacted in 1982 under the presidency of François Mitterrand, covered a wide range of aspects in both individual and collective labor law. Since that time, French labor law has mirrored changes in the distribution of power between the main political parties (Deakin, Lele, and Siems 2007).

While political forces are critical in shaping labor regulation, Saint-Paul (2002a) argues that the political impetus for employment protection legislation is itself closely linked to economic growth in a country. He asserts that higher rates of economic growth reduce the political support for dismissal laws. However, since incumbent workers are most fearful of losing jobs during periods of slow economic growth, the level of political support for dismissal laws should be high in such periods. As empirical evidence for his thesis, Saint-Paul (2002a) points out that employment protection increased in many European countries in the early 1970s and was difficult to reduce in the 1980s, as this was a period of slow economic growth.

\section{Theoretical Motivation}

\subsection{Theoretical Arguments Underlying the Hypotheses}

Acharya, Baghai, and Subramanian (2014) present a theoretical framework that also serves as the main motivation for our tests in this paper. The model features an all-equity firm choosing between two projects that differ mainly in their degree of innovation. For instance, in the case of a pharmaceutical company, these two projects can be thought of as inventing and launching a new drug or manufacturing and launching a generic substitute for an existing drug. Launching a generic substitute involves uncertainties due to customer demand and competition. In contrast, inventing and launching a new drug, while resulting in higher terminal payoffs in the case of success, entails additional uncertainties associated with the process of exploration and discovery and, thus, involves significantly more risk.

The firm, which is risk neutral, hires a risk-averse employee to work on the project; the employee is particularly averse to the risk of being dismissed from employment. A key friction in the model is that contracts are incomplete in the spirit of the theory on property rights (Grossman and Hart 1986; Hart and Moore 1990; Hart 1995). As highlighted by this theory, bilateral relationships can suffer from holdup problems when contracts are incomplete. Since the "opportunity for bad faith and the duty of good faith are products of incomplete contracts" (Bagchi 2003, p. 1886) when contracts are incomplete, an employer and an employee cannot commit to a contract that prohibits either of them from acting in bad faith ex post.

Contractual incompleteness introduces the possibility of holdup, where the firm fires the employee after an innovation is successful. As the payoffs from a successful innovation are often large, innovative firms may not be able to credibly 
commit ex ante to not arm-twist employees ex post to appropriate a larger share of the ex post surplus. The likelihood of such holdup, in turn, dampens the ex ante innovative effort by the employee. Given this friction, dismissal laws impose limits on the firm's ability to discharge an employee in bad faith after a successful innovation. By reducing the possibility of holdup, these laws enhance employees' innovative efforts and encourage firms to invest in risky but potentially moldbreaking projects. ${ }^{5}$ Thus, stringent dismissal laws may lead to more risk taking and innovation.

Alternatively, stringent dismissal laws may also encourage shirking by employees, resulting in lower levels of innovative effort and less innovation. Furthermore, laws and regulations could be incomplete in ways similar to contracts; legal incompleteness and uncertainty stemming from interpretation of legal rules by courts may lead to underinvestment in innovative effort. We examine empirically in Section 6 whether the effect of dismissal laws on innovation is positive or negative.

Given the unknown unknowns that characterize innovative ventures, contractual incompleteness and the consequent temptation to act in bad faith are more likely in innovative industries than in less innovative ones. Consequently, dismissal laws may play a more important role in alleviating the underinvestment problem in innovative industries. Thus, the effect of dismissal laws on innovation is likely to be disproportionately more pronounced in innovative industries than in less innovative ones.

Alternatively, the institutional environment may endogenously respond to the greater likelihood of holdup in innovation-intensive industries. ${ }^{6}$ For example, innovation-intensive industries (as opposed to less innovative ones) may develop sophistication in describing the complexities involved in innovative activities in an ex ante contract. Also, before a change in dismissal law, innovation may have been concentrated only in industries where contractual incompleteness and holdup are not important concerns. In either case, we should see no impact of the changes in dismissal laws on innovation in the innovation-intensive sectors. The tests in Section 6 shed light on the intraindustry effects of changes in dismissal law.

\subsection{Discussion}

Could parties commit to features in the employment contract to avoid inefficiencies stemming from contractual incompleteness? According to Tirole (1999), the complexities involved in innovative ventures make it difficult to comprehensively describe innovative activities, making it difficult to commit ex

\footnotetext{
${ }^{5}$ As innovative projects are riskier than routine projects, the lower threat of termination (induced by stronger dismissal laws) matters more for innovative projects than for routine projects. This leads the employee to increase his or her investment relatively more with the innovative project than with the routine project. Since an increase in the employee's investment increases the likelihood of a project's success, a disproportionate increase in the employee's investment in the innovative project (relative to the routine project) leads to a similar increase in the value of the project. Therefore, the firm finds risky, innovative projects to be more value enhancing than routine projects.

${ }^{6}$ We would like to thank the referee for highlighting this possibility.
} 
ante to avoid Pareto-improving renegotiation ex post, which reduces the credibility of any ex ante commitment through contractual features. ${ }^{7}$ Consider severance packages, for example. Empirical evidence indicates that for employees below the level of senior management in a firm, such severance packages are quite uncommon. ${ }^{8}$ This observation is consistent with the argument in Manso (2011), who shows that even when complete contracts can be written, the firm may find it prohibitively costly ex ante to commit to not fire its employees ex post.

The ex ante allocation of property rights to innovation outcomes can also affect the likelihood of an innovation (Aghion and Tirole 1994; Hart 1995). In particular, the employee's incentives to exert effort are greater if the employee owns the property rights to the innovation than if the employer is the owner. However, such an allocation of property rights is uncommon in practice. ${ }^{9}$ Thus, the commonly observed employer ownership of property rights may exacerbate the market failure that leads to the positive effect of dismissal laws on innovation hypothesized in Section 4.1.

Apart from the employer holding up the employee, the employee could also hold up the employer, for example, by stealing trade secrets and then seeking employment elsewhere. Noncompete covenants, which expressly forbid employees from indulging in such holdup, are common in employment contracts, particularly for technical workers and upper-level management. ${ }^{10}$ However, the effects of dismissal laws on innovation differ from those of legal restrictions on the mobility of human capital. Dismissal laws primarily have the effect of limiting an employer's ability to hold up the employee when the innovation is firm specific (and therefore has to be implemented within the incumbent firm). In contrast, legal restrictions on the mobility of human capital limit the employee's ability to hold up the firm when the innovation is generic (and can therefore be implemented by the employee in a new firm). By exploiting the fact that innovations can be either firm specific or generic, Acharya, Baghai, and Subramanian (2014) show in an extension to their basic model that the positive effect of dismissal laws on innovation remains robust to accounting for the presence of legal restrictions on mobility of human capital.

\footnotetext{
${ }^{7}$ Given these difficulties, revenue-sharing rules or severance payments contracted ex ante, contracts that explicitly specify ex post performance, or messaging mechanisms cannot fully address the incentive problems generated by contractual incompleteness (for details, see Hart 1995).

${ }^{8}$ Narayanan and Sundaram (1998) find that only 7 percent of the Fortune 1000 and Standard \& Poor 500 nonfinancial firms examined from 1980 to 1994 had "tin parachutes," that is, severance agreements for employees who are not officers of the company. Furthermore, the incidence of tin parachutes was limited to change-of-control events such as a merger or acquisition.

${ }^{9}$ For example, according to Coolley (1985), 84 percent of American patents are awarded to employed inventors, and almost all of these patents are assigned to the inventors' employers. Furthermore, employment contracts usually specify that an innovation made by an employee shortly after quitting the firm belongs to the former employer (see Aghion and Tirole 1994, citing Neumeyer 1971, p. 1199).

${ }^{10}$ In the United States, for example, surveys report that nearly 90 percent of such employees have signed noncompete agreements (Kaplan and Strömberg 2003).
} 


\section{Empirical Analysis}

\subsection{Why Focus on Innovation?}

Our theoretical arguments above apply broadly to the effect of dismissal laws on risk taking, not only in the context of innovation. However, our focus on innovation is motivated by the following considerations. First, as argued in the introduction, endogenous-growth theory highlights the central role of laws and institutions that foster innovative investment and thereby significantly stimulate economic growth. Therefore, the role of labor laws in fostering innovation (even if as an unintended consequence) is of broad interest to academics and policy makers alike.

Focusing on innovation also offers significant advantages from an empirical perspective. The risks involved in a project can only be measured based on the variance in the outcomes from the project. Patents-which have long been used as proxies for innovative activity (see Griliches 1981; Pakes and Griliches 1980; Griliches 1990)—represent such outcome-based measures of risky, innovative investments. In contrast, neither capital expenditures (CAPEX) nor R\&D expenditures, which are input-based measures of investment, provide this advantage.

Furthermore, unlike CAPEX or R\&D expenditures, the quality of the risky investment can be measured using the trail of citations to patents. A simple count of patents does not distinguish breakthrough innovations from less significant or incremental technological discoveries. ${ }^{11}$ In contrast, citations capture the economic importance and drastic nature of innovation, which enables us to proxy for the value-enhancing aspect of innovative activities. Intuitively, the rationale behind using patent citations to identify important innovations is as follows: if firms are willing to further invest in a project that is building on a previous patent, the cited patent is likely to be influential and economically significant. Furthermore, patent citations accumulate over time, and the importance of an investment may be revealed later in its life and may be difficult to evaluate when the investment occurs. Since our patent data record all future citations (until 2002) made to a patent, the quality and value of the investment can be measured.

Finally, our theoretical motivation also suggests that risk taking with respect to innovative projects increases after the passage of stricter dismissal laws. The standard deviation of the citations received by patents can be used as a direct proxy for the risk involved in an innovative project.

\subsection{Proxies for Innovation}

We follow Acharya and Subramanian (2009) in using U.S. patents to proxy innovation by international firms. To construct these proxies for innovation, we

\footnotetext{
${ }^{11}$ Pakes and Schankerman (1984) show that the distribution of the importance of patents is extremely skewed; that is, most of the value is concentrated in a small number of patents. Hall, Jaffe, and Trajtenberg (2005), among others, demonstrate that patent citations are a good measure of the value of innovations.
} 
use data on patents filed with the USPTO and the citations to these patents, compiled by Hall, Jaffe, and Trajtenberg (2001) in the National Bureau of Economic Research (NBER) U.S. Patent Citation Data File. The NBER patent data set provides, among other items, annual information on patent assignee names, the number of patents, the number of citations received by each patent, the technology class of the patent, and the year that the patent application was filed. The data set covers all patents filed with the USPTO by firms from around 85 countries. We exploit the technological dimension of the data generated by patent classes. The USPTO assigns patents to about 500 patent classes to facilitate future searches of the prior work (see Kortum and Lerner 1999).

We follow the practice in the patent literature of dating the patents by the year of the application. This avoids anomalies that may be created because of the lag between the date of application and the date of granting the patent (Hall, Jaffe, and Trajtenberg 2001). Note that although we use the application year for our analysis, the patents appear in the database only after they are granted. Hence, we use the patents actually granted (rather than the patent applications) for our analysis.

We employ the number of patents and citations to these patents as our primary proxies for innovation. To capture innovative risk taking by firms, we also employ the standard deviation of citations. For each country and year (country, patent class, and year), we first sum the number of citations each firm receives; we then calculate the standard deviation of these citations per country and year (country, patent class, and year).

\subsection{Changes in Dismissal Law}

Deakin, Lele, and Siems (2007) use the indexing method to code the differences between the legal systems of five countries (United States, United Kingdom, France, Germany, and India) as they relate to labor law. ${ }^{12}$ They categorize labor law into five areas: the regulation of alternative forms of labor contracting (for example, self-employment, part-time work, and contract work), regulation of working time, employee representation, rules governing industrial action, and regulation of dismissal. They analyze in detail the evolution of employment protection legislation along these five dimensions in the five countries from 1970 to 2006. They translate individual law changes into changes in a labor law index,

12 The Botero et al. (2004) index presents an alternative to the Deakin, Lele, and Siems (2007) index that we use. Although the Botero et al. (2004) index is constructed for 85 countries, it is available only for the year 1997. Therefore, it is not suitable for investigating the causal impact of labor laws on innovation, which necessitates controlling for observable and unobservable time-varying heterogeneity. Another alternative is the employment protection legislation measure constructed by Nicoletti and Scarpetta (2001) for a set of Organisation for Economic Co-operation and Development countries for the years 1990-98. However, this index offers neither the cross-sectional comprehensiveness of the index constructed by Botero et al. (2004) nor the full extent of the longitudinal advantages of the index developed by Deakin, Lele, and Siems (2007). Furthermore, the employment protection legislation index measures only the aggregate stringency of a country's labor laws, while in this study we are interested in one particular dimension of these laws, namely, dismissal rules. 
in which higher values indicate a higher degree of protection of the interests of employees vis-à-vis employers.

The Deakin, Lele, and Siems (2007) index offers several advantages. First, the long time series, which captures comprehensively all country-level changes in labor laws, enables us to conduct difference-in-differences tests that alleviate econometric concerns about country-level omitted variables. Second, the categorization of labor laws into different components allows us to assess the impact on innovation of dismissal laws vis-à-vis other categories of labor laws. Third, the index takes into account not only formal laws but also self-regulatory mechanisms, which makes it particularly comprehensive with respect to the range of rules analyzed. For example, in certain legal systems, collective bargaining agreements-which do not constitute formal law-play a role that is functionally similar to formally enacted laws. Finally, the numerical values reported in the index are complemented by a detailed description of all the relevant law changes in each country.

Guided by our theoretical motivation, we mainly focus on one dimension of labor laws, namely, dismissal laws-laws that prevent employers from arbitrarily discharging employees - and how such laws affect firms' innovation. Deakin, Lele, and Siems (2007) code dismissal laws as a specific subindex of the labor law index. This subindex (hereafter the dismissal law index or regulation-ofdismissal index) consists of the following dimensions of employment protection legislation: rules governing unjust dismissal, the legally mandated notice period, the amount of mandatory redundancy compensation, constraints on dismissal imposed by the law, parties to be notified in case of dismissal, redundancy selection, and applicability of priority rules in reemployment. (See the Appendix for a more detailed discussion of the index components.) Figures 1-4 depict the evolution of the dismissal law index for the four countries in the sample; higher values represent stricter laws governing dismissal. The figures show the real GDP growth rate for each country and business cycle troughs (dotted vertical line). ${ }^{13}$ It is clear from the figures that while stricter dismissal laws are more likely to be passed in periods of economic contractions, this relationship is not strong (the correlation equals -.18). Nonetheless, we control for real GDP growth in the tests that follow.

Table 1 details each change in dismissal law during the period 1970-2006; these law changes generate the variation observed in Figures 1-4. As an illustration, consider a few specific law changes. In France, before 1973, an employer was not required to notify an employee in case of a dismissal. In 1973, this aspect of dismissal law was strengthened by requiring the employer to provide the employee with written reasons for the dismissal. This change is reflected as an increase of .0367 in the regulation-of-dismissal index. In 1975, the law was

\footnotetext{
${ }^{13}$ Data on gross domestic product growth are from Penn World Table (Heston, Summers, and Aten 2009), country-specific business cycle data are from the Economic Cycle Research Institute, About Business Cycles (http://www.businesscycle.com/ecri-business-cycle-definition), and the dismissal law index is from Deakin, Lele, and Siems (2007).
} 


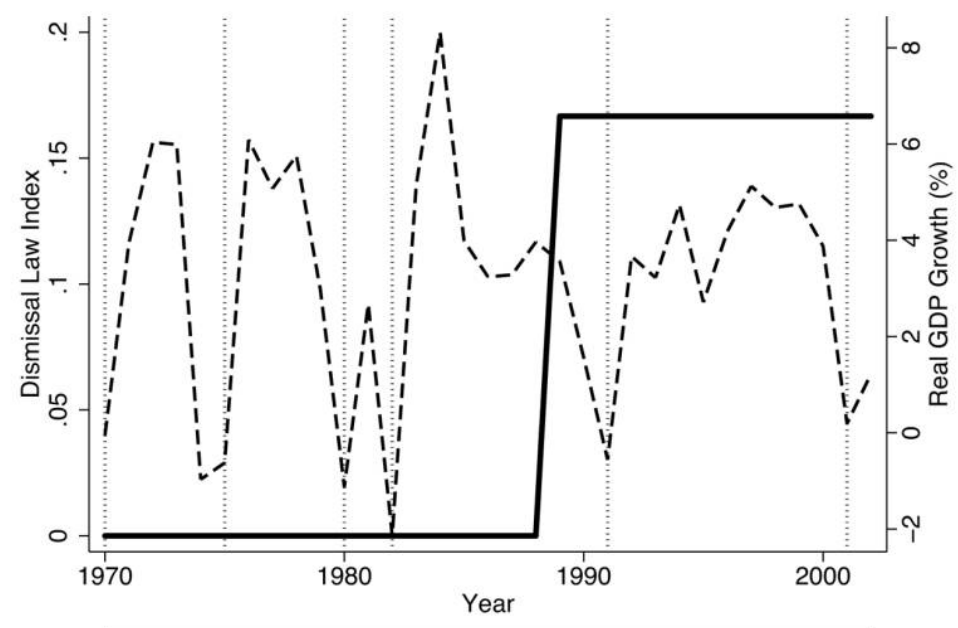

- - - - Real GDP Growth (\%) — Dismissal Law Index

Figure 1. Dismissal laws, gross domestic product growth, and business cycle troughs: United States.

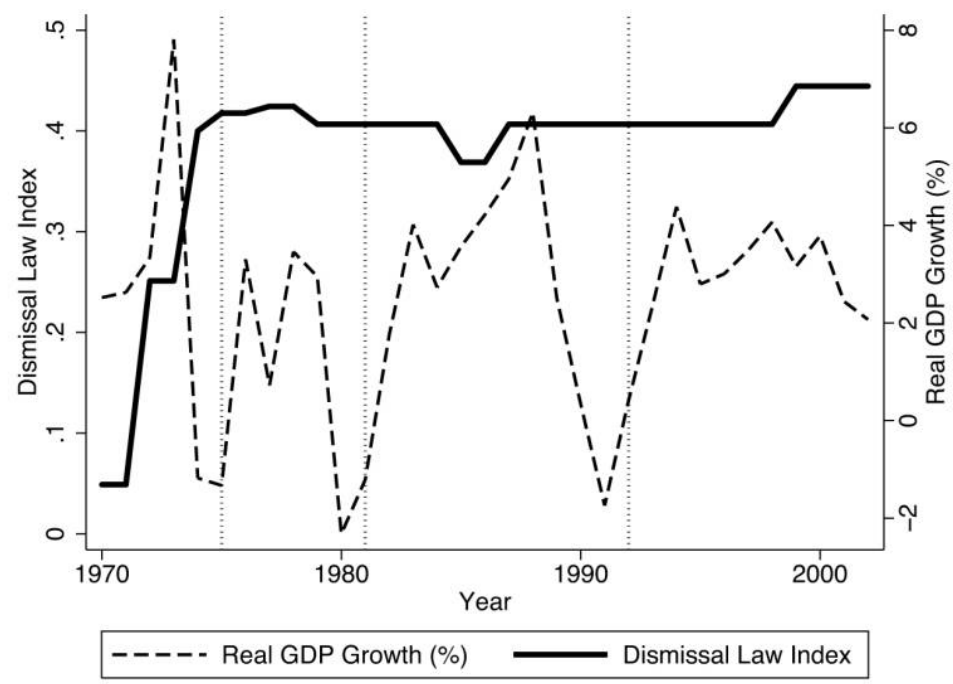

Figure 2. Dismissal laws, gross domestic product growth, and business cycle troughs: United Kingdom.

This content downloaded from 202.174.120.162 on June 08, 2019 06:50:15 AM

All use subject to University of Chicago Press Terms and Conditions (http://www.journals.uchicago.edu/t-and-c). 


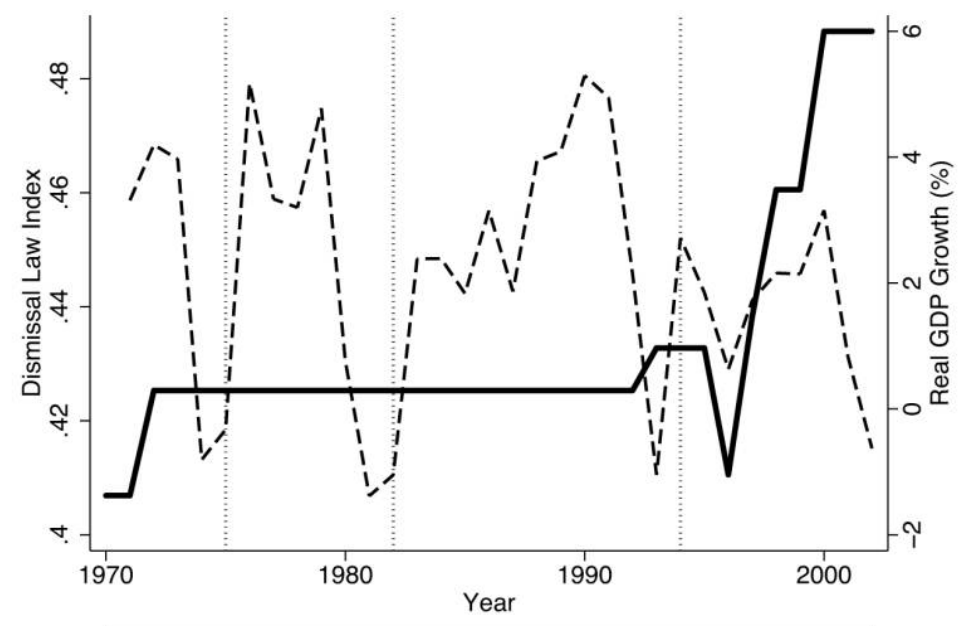

- - - - Real GDP Growth (\%) — Dismissal Law Index

Figure 3. Dismissal laws, gross domestic product growth, and business cycle troughs: Germany.

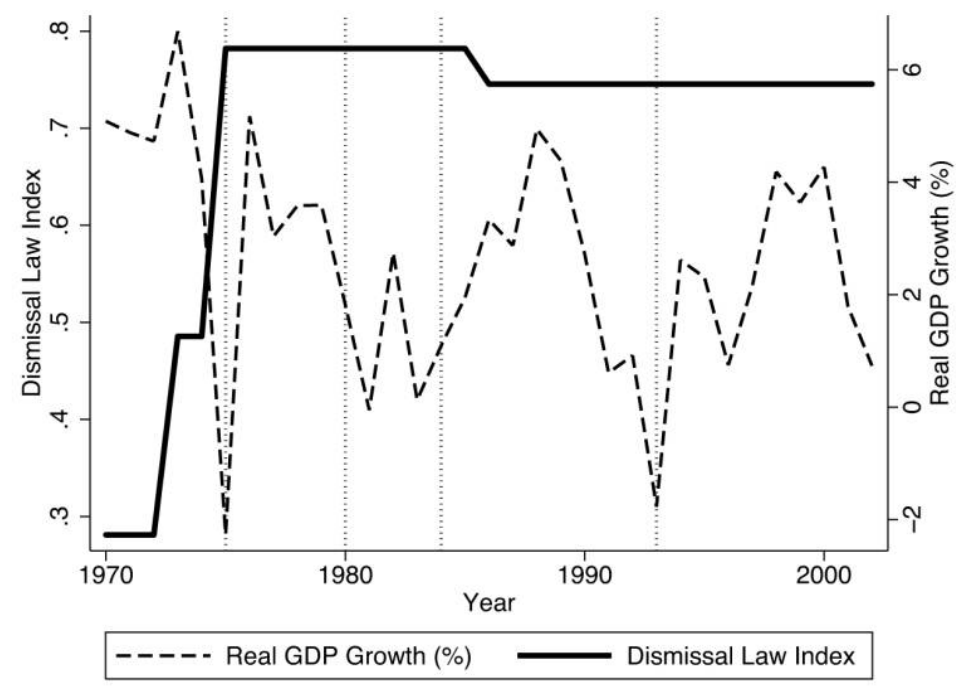

Figure 4. Dismissal laws, gross domestic product growth, and business cycle troughs: France.

\section{1}

This content downloaded from 202.174.120.162 on June 08, 2019 06:50:15 AM

All use subject to University of Chicago Press Terms and Conditions (http://www.journals.uchicago.edu/t-and-c). 


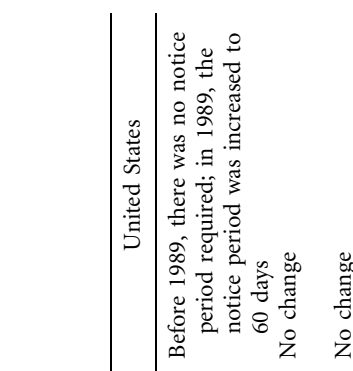

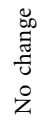

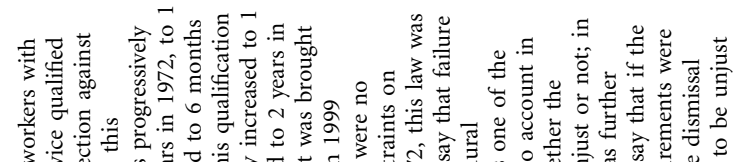
3.

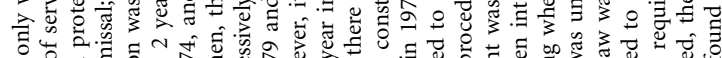

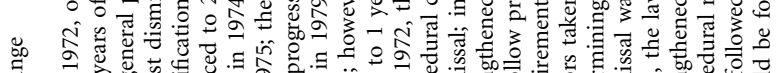

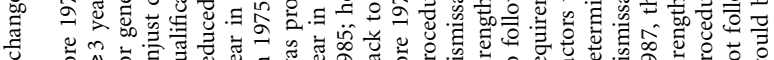

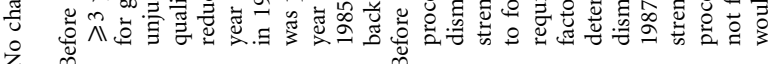

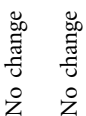
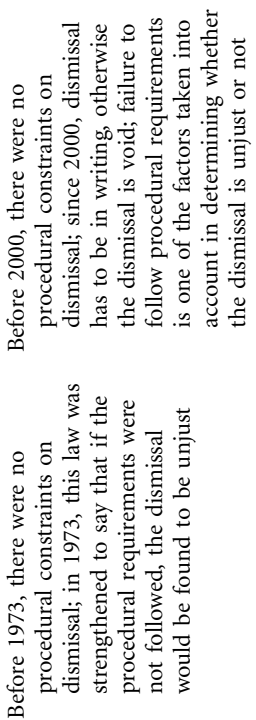

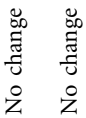

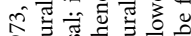
9 琎.

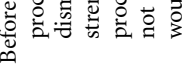
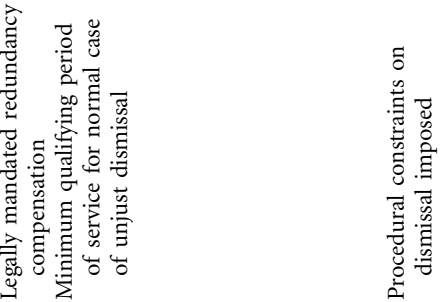

This content downloaded from 202.174.120.162 on June 08, 2019 06:50:15 AM All use subject to University of Chicago Press Terms and Conditions (http://www.journals.uchicago.edu/t-and-c). 


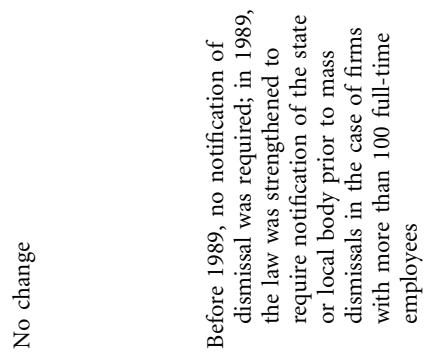

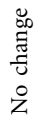
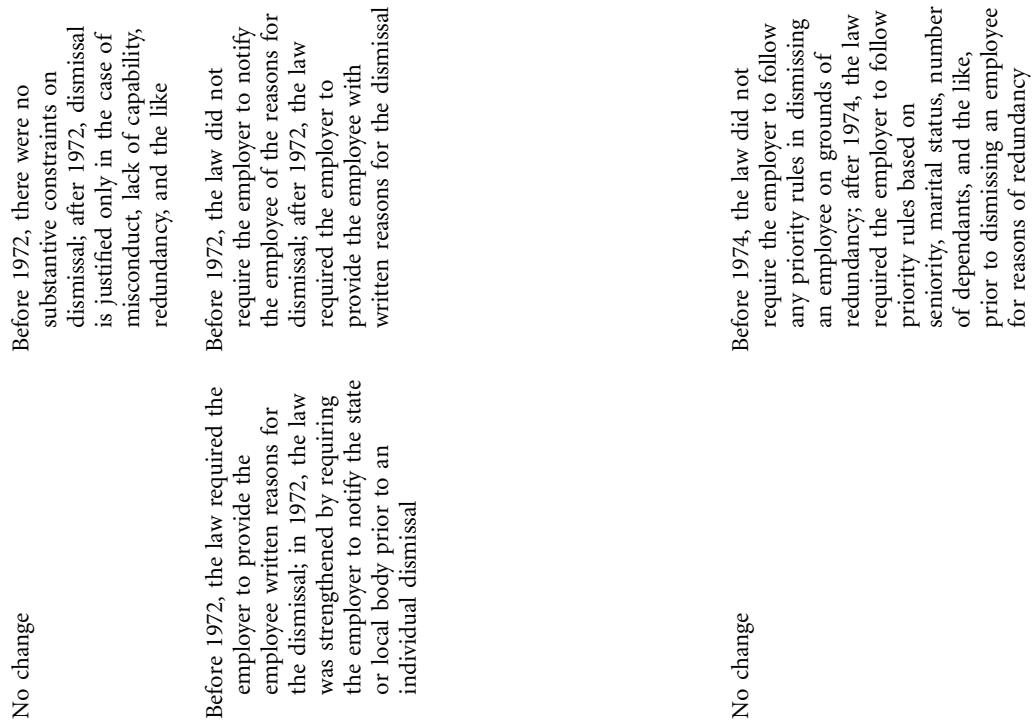

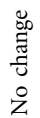
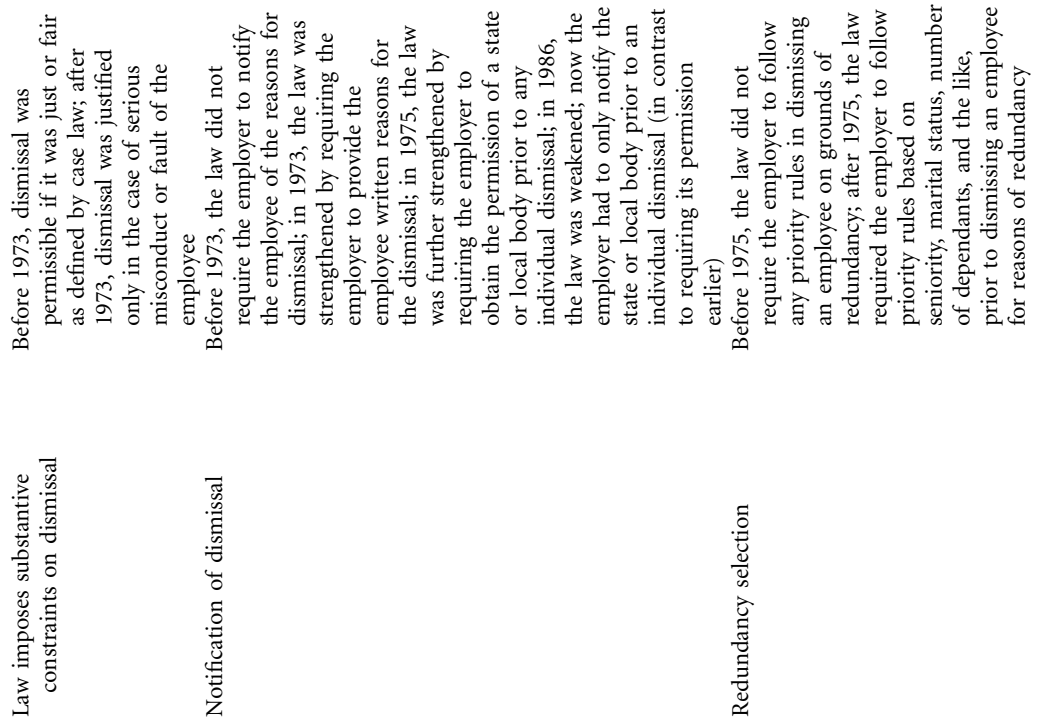

苞

\section{3}

This content downloaded from 202.174.120.162 on June 08, 2019 06:50:15 AM All use subject to University of Chicago Press Terms and Conditions (http://www.journals.uchicago.edu/t-and-c). 


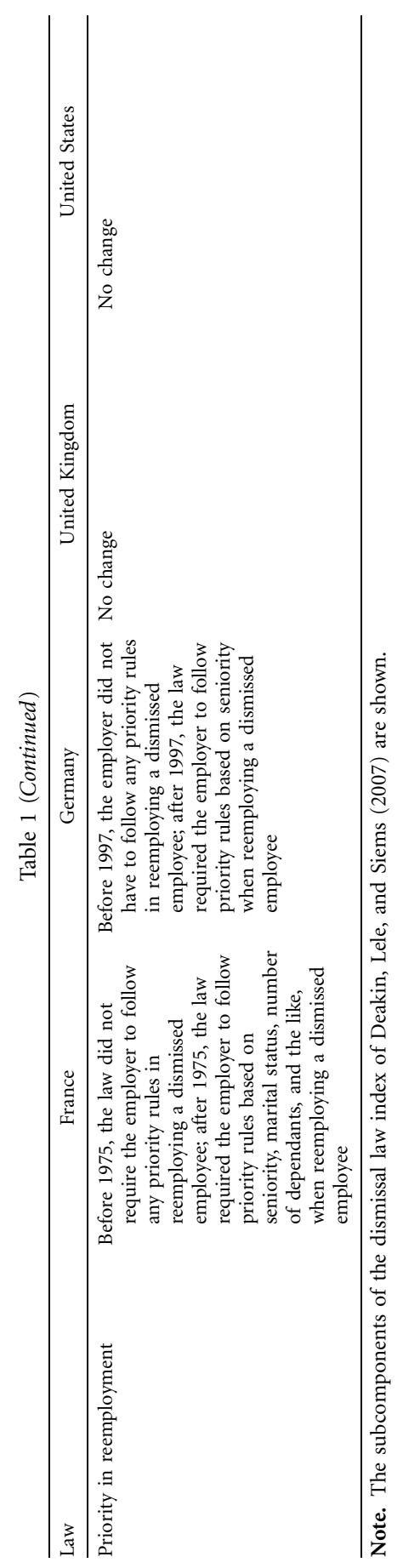

This content downloaded from 202.174.120.162 on June 08, 2019 06:50:15 AM All use subject to University of Chicago Press Terms and Conditions (http://www.journals.uchicago.edu/t-and-c). 
further strengthened, and the employer had to obtain the permission of a state or local body prior to any individual dismissal; this law change results in an increase of .0744 in the regulation-of-dismissal index. In 1986, this law was weakened; now the employer only had to notify the state or local body prior to an individual dismissal (in contrast to requiring its permission earlier), which resulted in a decrease of .0367 in the regulation-of-dismissal index. Figures 14 (and Table 1) indicate that the numerous legal changes provide substantial time-series variation, which we exploit in our statistical tests.

\subsubsection{Summary Statistics}

We report summary statistics for each of the countries in Table 2, separately for the country-, industry-, and firm-level samples. The dismissal law index is available from 1970 to 2006, while the patent data end in 2002.

A casual look at the summary statistics suggests that, across countries, more stringent dismissal laws tend to be associated with less innovation. This intercountry variation may be driven by many factors other than dismissal laws, factors that are omitted in a simple comparison of time-series averages. The tests in Section 6 are designed to address such concerns of endogeneity. By exploiting variation within countries (and industries) over time, they answer whether within a given country, increases in dismissal protection lead to more or less innovation activity.

\section{Results}

\subsection{Fixed-Effects Panel Regressions Using the Country-Level Sample}

\subsubsection{Basic Tests}

First, we estimate fixed-effects panel regressions with innovation proxies as dependent variables and the dismissal law index as explanatory variable:

$$
y_{c t}=\beta_{c}+\beta_{t}+\beta_{1} \times \text { DismissalLaws }_{c, t-k}+\beta \boldsymbol{X}_{c t}+\varepsilon_{c t}
$$

where $y_{c t}$ is the natural logarithm of a measure of innovation from country $c$ in year $t$. DismissalLaws ${ }_{c, t-k}$ denotes the $k$ th lag of the dismissal law index for country $c$, measuring the stringency of dismissal laws. The impact of dismissal laws on our innovation proxies is measured by $\beta_{1}$. The term $\boldsymbol{X}_{c t}$ is a set of control variables. The country fixed effects $\beta_{c}$ control for time-invariant unobserved factors at the country level. The application year fixed effects $\beta_{t}$ account for global technological shocks; further, they allow us to control for the problem stemming from the truncation of citations - that is, the number of citations to patents applied for in later years is on average lower than the number of citations to patents applied for in earlier years. The term $\beta_{1}$ in equation (1) estimates the difference in differences in a generalized setting of multiple treatment groups and multiple time periods (see Imbens and Wooldridge 2009). 
Table 2

Dismissal Law Index: Summary Statistics

\begin{tabular}{|c|c|c|c|c|c|c|}
\hline & $N$ & Mean & Median & SD & Min & Max \\
\hline \multicolumn{7}{|l|}{ United States: } \\
\hline \multicolumn{7}{|l|}{ Country level: } \\
\hline Patents & 33 & $36,409.300$ & 30,736 & $15,421.220$ & 647 & 72,309 \\
\hline Citations & 33 & $259,106.400$ & 264,072 & $116,381.500$ & 4 & 411,595 \\
\hline SD of citations & 33 & 195.661 & 221.858 & 83.794 & .121 & 307.078 \\
\hline Dismissal law index & 33 & .071 & 0 & .084 & 0 & 167 \\
\hline \multicolumn{7}{|l|}{ Industry level: } \\
\hline Patents & 9,869 & 96.759 & 46 & 160.345 & 1 & 2,879 \\
\hline Citations & 9,869 & 664.485 & 223 & $1,213.845$ & 0 & 12,116 \\
\hline SD of citations & 9,470 & 18.756 & 9.669 & 27.781 & 0 & 319.853 \\
\hline Dismissal law index & 9,869 & .093 & .167 & .083 & 0 & 167 \\
\hline \multicolumn{7}{|l|}{ Firm level: } \\
\hline CAPEX/Assets & 107,969 & .064 & .040 & .075 & 0 & 424 \\
\hline $\mathrm{R} \& \mathrm{D} /$ Assets & 109,884 & .071 & 0 & .160 & 0 & 949 \\
\hline Dismissal law index & 118,860 & .167 & .167 & 0 & .167 & .167 \\
\hline \multicolumn{7}{|l|}{ United Kingdom: } \\
\hline \multicolumn{7}{|l|}{ Country level: } \\
\hline Patents & 33 & $2,239.182$ & 2,257 & 643.208 & 23 & 3,468 \\
\hline Citations & 33 & $12,200.970$ & 14,333 & $5,578.060$ & 0 & 17,535 \\
\hline SD of citations & 33 & 45.479 & 52.854 & 24.394 & 0 & 84.478 \\
\hline Dismissal law index & 33 & .379 & .407 & .095 & .049 & .444 \\
\hline \multicolumn{7}{|l|}{ Industry level: } \\
\hline Patents & 7,330 & 7.548 & 4 & 13.174 & 1 & 286 \\
\hline Citations & 7,330 & 38.348 & 15 & 70.408 & 0 & 1,145 \\
\hline SD of citations & 5,647 & 7.277 & 4.359 & 9.323 & 0 & 106.196 \\
\hline Dismissal law index & 7,330 & .409 & .407 & .017 & .369 & 444 \\
\hline \multicolumn{7}{|l|}{ Firm level: } \\
\hline CAPEX/Assets & 17,534 & .060 & .040 & .068 & 0 & .424 \\
\hline $\mathrm{R} \& \mathrm{D} /$ Assets & 20,118 & .021 & 0 & .082 & 0 & .949 \\
\hline Dismissal law index & 20,161 & .419 & 407 & .018 & .407 & 444 \\
\hline \multicolumn{7}{|l|}{ Germany: } \\
\hline \multicolumn{7}{|l|}{ Country level: } \\
\hline Patents & 33 & 5,950 & 5,601 & $1,889.322$ & 83 & 9,881 \\
\hline Citations & 33 & $26,377.520$ & 30,457 & $12,040.700$ & 0 & 39,107 \\
\hline SD of citations & 33 & 98.644 & 120.443 & 47.630 & 0 & 157.478 \\
\hline Dismissal law index & 33 & .433 & .425 & .021 & .407 & 488 \\
\hline \multicolumn{7}{|l|}{ Industry level: } \\
\hline Patents & 8,615 & 18.384 & 10 & 24.941 & 1 & 349 \\
\hline Citations & 8,615 & 75.245 & 32 & 116.419 & 0 & 1,313 \\
\hline SD of citations & 7,616 & 9.248 & 5.378 & 12.483 & 0 & 174.062 \\
\hline Dismissal law index & 8,615 & .434 & .425 & .019 & .411 & .488 \\
\hline \multicolumn{7}{|l|}{ Firm level: } \\
\hline CAPEX/Assets & 5,681 & .065 & .045 & .070 & 0 & 424 \\
\hline $\mathrm{R} \& \mathrm{D} /$ Assets & 8,183 & .016 & 0 & .049 & 0 & 949 \\
\hline Dismissal law index & 8,193 & .481 & 488 & .045 & .411 & .549 \\
\hline \multicolumn{7}{|l|}{ France: } \\
\hline \multicolumn{7}{|l|}{ Country level: } \\
\hline Patents & 33 & $2,128.970$ & 1,841 & 787.877 & 17 & 3,732 \\
\hline Citations & 33 & $9,741.061$ & 11,354 & $4,367.941$ & 0 & 14,649 \\
\hline SD of citations & 33 & 42.195 & 49.572 & 19.850 & 0 & 74.540 \\
\hline Dismissal law index & 33 & .700 & .746 & .151 & .281 & .782 \\
\hline
\end{tabular}

This content downloaded from 202.174.120.162 on June 08, 2019 06:50:15 AM

All use subject to University of Chicago Press Terms and Conditions (http://www.journals.uchicago.edu/t-and-c). 
Table 2 (Continued)

\begin{tabular}{lcrcccr}
\hline & $N$ & Mean & Median & SD & Min & \multicolumn{1}{c}{ Max } \\
\hline Industry level: & & & & & & \\
$\quad$ Patents & 7,293 & 7.791 & 5 & 12.125 & 1 & 250 \\
$\quad$ Citations & 7,293 & 33.020 & 14 & 53.694 & 0 & 747 \\
$\quad$ SD of citations & 5,639 & 7.096 & 4 & 10.377 & 0 & 163.613 \\
$\quad$ Dismissal law index & 7,293 & .758 & .746 & .017 & .746 & .782 \\
Firm level: & & & & & & .424 \\
$\quad$ CAPEX/Assets & 5,868 & .056 & .039 & .060 & 0 & .949 \\
$\quad$ R\&D/Assets & 8,159 & .010 & 0 & .043 & 0 & .746 \\
$\quad$ Dismissal law index & 8,218 & .746 & .746 & 0 & .746 & .746 \\
\hline
\end{tabular}

Sources. Patent data are from Hall, Jaffe, and Trajtenberg (2001). The labor law index data are from Deakin, Lele, and Siems (2007). Firm-level data are from Compustat.

Note. Data span the years 1970-2002 in the country-level sample, 1978-2002 in the industry-level sample, and 1989-2006 in the firm-level sample. CAPEX = capital expenditures; R\&D = research and development.

Figure 5 illustrates the difference in differences for the change in laws governing dismissal in the United States in 1989, when the Worker Adjustment and Retraining Notification Act became effective at the federal level. Because Germany did not experience a change in dismissal laws in 1989, Germany serves as the control group. ${ }^{14}$ In Figure 5, we plot across time the ratio of the realized number of patents in a particular year to that in 1989-the year of the change in the U.S. dismissal law. We find that while the number of patents is relatively in sync for the United States and Germany until 1989, after 1989 these measures for the United States outpace those for Germany.

Table 3 shows the results of the test of equation (1). In the first tests, we do not include any time-varying control variables. Employing the first and second lags of the dismissal law index as explanatory variables in different specifications enables us to estimate the impact of changes in dismissal law on innovation 1 and 2 years after the change. In tests that we omit in the interest of brevity, we also found similar effects on innovation 3 years after the change. Overall, the coefficient of dismissal laws is positive and significant, which indicates that stronger dismissal laws are positively correlated with innovation, as suggested by hypothesis 1 .

Because we identify the hypothesized effect using specific law changes, we also assess the economic magnitude of the effect using individual law changes. Consider the effect of the law changing procedural constraints on dismissal in the United Kingdom in 1987, when it became harder for employers to avoid a finding of unjust dismissal in case of a lack of due process. This law change corresponds to an increase of .0378 in the dismissal law index. Using columns 1-3 of Table 3 , we find that this law change corresponds to an increase in the annual number of patents, number of citations, and standard deviation of citations by 1.3 percent, 1.6 percent, and 2.2 percent, respectively.

\footnotetext{
${ }^{14}$ The U.S. Worker Adjustment and Retraining Notification Act (29 U.S.C. 2101-2109) was passed in 1988 and took effect in 1989. Germany experienced no changes in dismissal law between 1973 and 1992.
} 


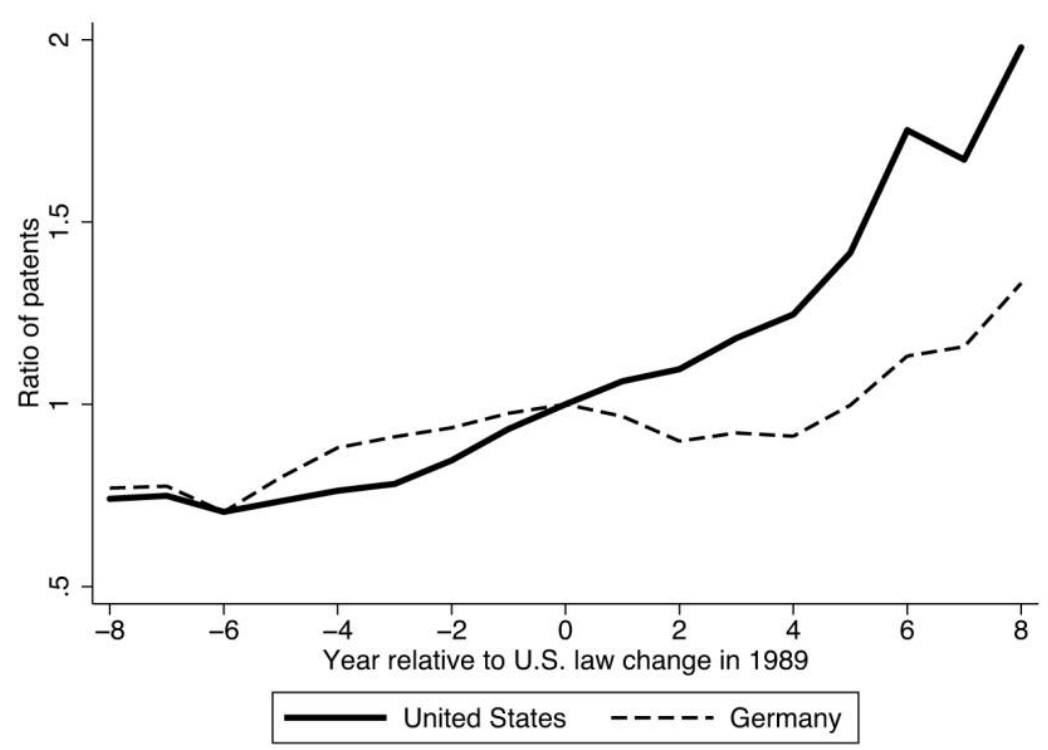

Figure 5. Innovation and dismissal laws: United States versus Germany

\subsubsection{Tests Controlling for Other Country-Level Effects}

Next, we repeat these tests after adding control variables that enable us to account for other time-varying determinants of innovation. Acharya and Subramanian (2009) provide empirical evidence that when a country's bankruptcy code is creditor friendly, excessive liquidations cause leveraged firms to shun innovation, whereas by promoting continuation upon failure, a debtor-friendly code induces greater innovation. Therefore, we control for the extent of creditor protection in a country by using the time-varying index of creditor rights developed by Armour et al. (2009). ${ }^{15}$ Furthermore, as the degree of innovation in

${ }^{15}$ The Armour et al. (2009) index is the sum of binary variables describing individual dimensions of creditor protection; these variables pertain to three groups: legal rules restricting the debtor from entering into transactions that may harm creditors' interests, variables describing credit contracts, and variables pertaining to liquidation procedures and rehabilitation proceedings. Higher values of the creditor rights index imply more creditor protection. For further details, see Armour et al. (2009). An alternative to using the Armour et al. (2009) index would be the Djankov, McLiesh, and Shleifer (2007) index of creditor rights. We employ the Armour et al. (2009) index for two reasons. First, as the coding is done by the same team of researchers, the methodology applied in the creditor index coding is consistent with the dismissal law index coding that we employ in this paper. Second, the Armour et al. (2009) index coding starts in 1970, as do most of the other data employed in this study, while the coding of Djankov, McLiesh, and Shleifer (2007) is available from 1978 only. However, results are similar when we employ the Djankov, McLiesh, and Shleifer (2007) index instead of the Armour et al. (2009) index. 


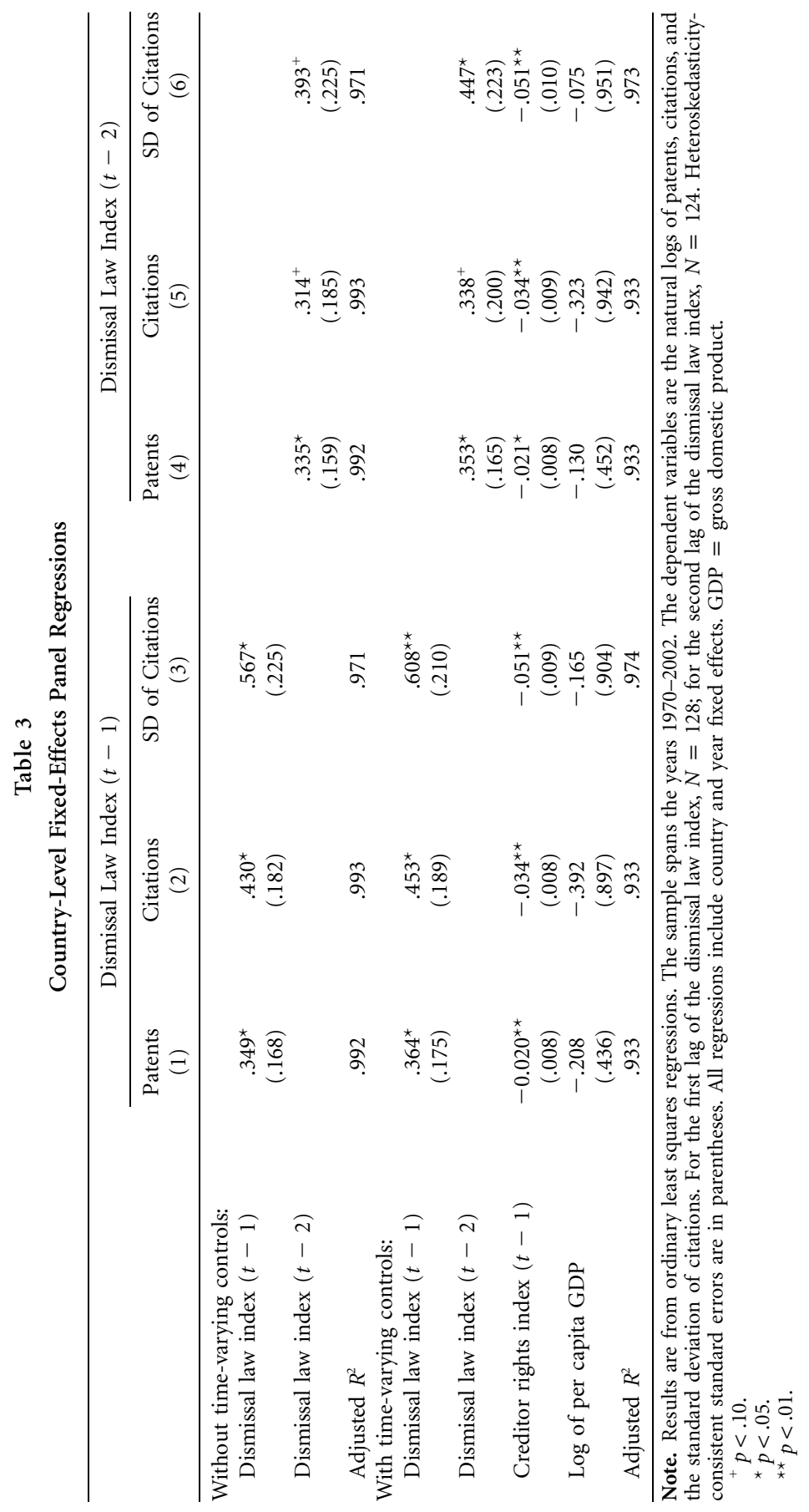

This content downloaded from 202.174.120.162 on June 08, 2019 06:50:15 AM All use subject to University of Chicago Press Terms and Conditions (http://www.journals.uchicago.edu/t-and-c). 
a country may vary with its level of economic development, we also control for the log of real GDP in a country and year (data from Penn World Table [Heston, Summers, and Aten 2009]). Table 3 also shows the results of these tests.

Consistent with Acharya and Subramanian (2009), we find that stronger creditor rights discourage innovation as seen in the negative and statistically significant coefficient of creditor rights. Moreover, we find a negative correlation between our proxies for innovation and the log of real GDP, although the coefficient is not statistically significant. Crucially, after including these controls, we find that the positive effect of dismissal laws on innovation persists. Furthermore, the coefficient magnitudes are very similar to those without timevarying controls.

\subsection{Dynamic Effects}

To investigate the possibility of reverse causality, we examine the dynamic effects of changes in dismissal laws on innovation. To this end, we include the contemporaneous dismissal law index and up to three lags and forward values of the dismissal law index. Furthermore, we examine the persistence of the effect of changes in dismissal law on subsequent innovation activity by also including the sixth lag of the dismissal law index. As in the results with time-varying controls in Table 3, we include creditor rights and log of per capita GDP as control variables.

We implement the model

$$
\begin{aligned}
y_{c t}= & \beta_{c}+\beta_{t}+\sum_{k=0}^{6} \beta_{k} \times \text { DismissalLaws }_{c, t+3-k} \\
& +\beta_{7} \times \text { DismissalLaws }_{c, t-6}+\beta \boldsymbol{X}_{c t}+\boldsymbol{\varepsilon}_{c t},
\end{aligned}
$$

where variables are as defined for equation (1). Table 4 shows the results of these regressions. A positive and significant coefficient on the lead terms of the dismissal law index would indicate an effect of dismissal laws prior to their actual passage and could therefore be symptomatic of reverse causation. Reassuringly, we observe that this is not the case: the effect of changes in dismissal law on innovation manifests only after their passage, not contemporaneously or prior to law passage. Changes in dismissal law have a long-run impact on innovation, as evidenced by the significant coefficient on the third lag of the dismissal index. However, these effects are smaller than the short-run effects, and they dissipate within 6 years after a change in dismissal law, as seen in the coefficient of the sixth lag of the dismissal law index being insignificant. 
Table 4

Dynamic Effects

\begin{tabular}{lccc}
\hline & $\begin{array}{c}\text { Patents } \\
(1)\end{array}$ & $\begin{array}{c}\text { Citations } \\
(2)\end{array}$ & $\begin{array}{c}\text { SD of Citations } \\
(3)\end{array}$ \\
\hline Dismissal law index $(t+3)$ & $-.684^{+}$ & .384 & .222 \\
& $(.406)$ & $(.371)$ & $(.860)$ \\
Dismissal law index $(t+2)$ & -.114 & .038 & .303 \\
& $. .458)$ & $(.464)$ & $(.894)$ \\
Dismissal law index $(t+1)$ & .435 & .676 & .857 \\
& $(.387)$ & $(.509)$ & $(.631)$ \\
Dismissal law index $(t)$ & .244 & -.129 & -.333 \\
& $(.308)$ & $(.592)$ & $(.736)$ \\
Dismissal law index $(t-1)$ & $1.188^{* *}$ & $1.970^{\star *}$ & $2.027^{\star *}$ \\
& $(.442)$ & $(.613)$ & $(.655)$ \\
Dismissal law index $(t-2)$ & .146 & -.291 & -.014 \\
& $(.344)$ & $(.385)$ & $(.306)$ \\
Dismissal law index $(t-3)$ & $.415^{+}$ & $.611^{\star}$ & $.828^{\star *}$ \\
& $(.234)$ & $(.258)$ & $(.288)$ \\
Dismissal law index $(t-6)$ & -.037 & -.014 & -.153 \\
& $(.113)$ & $(.107)$ & $(.169)$ \\
Creditor rights index $(t-1)$ & $-.024^{* *}$ & $-.034^{\star *}$ & $-.038^{\star *}$ \\
& $(.007)$ & $(.007)$ & $(.009)$ \\
Log of per capita GDP & $-.707^{\star}$ & $-1.224^{\star *}$ & $-1.772^{\star *}$ \\
& $(.281)$ & $(.364)$ & $(.561)$ \\
\hline
\end{tabular}

Note. Results are from ordinary least squares regressions. The dependent variables are the natural logs of patents, citations, and the standard deviation of citations. Heteroskedasticity-consistent standard errors are in parentheses. All regressions include country and year fixed effects. $N=96$. Adjusted $R^{2}$ $=.997$ for patents, .997 for citations, and .986 for SD of citations. GDP $=$ gross domestic product. ${ }^{+} p<.10$.

${ }^{*} p<.05$.

$* * p<.01$.

\subsection{Fixed-Effects Panel Regressions Using the Industry-Level Sample}

Next, we exploit variation in innovation within industries by measuring our innovation proxies at the country and industry level. We employ the following ordinary least squares models to test our hypotheses:

$$
\begin{aligned}
y_{i c t}= & t \beta_{j \leftarrow i}+t \beta_{c}+\beta_{i}+\beta_{c}+\beta_{t}+\beta_{1} \times \text { DismissalLaws }_{c, t-k} \\
& +\beta \times \boldsymbol{X}_{i c t}+\varepsilon_{i c t}
\end{aligned}
$$

where $y_{i c t}$ is the natural logarithm of a measure of innovation for the USPTO patent class $i$ from country $c$ in year $t$. The patent class fixed effects $\beta_{i}$ control for average differences in technological advances across the different industries as well as time-invariant differences in patenting and citation practices across industries. The term $t \beta_{j \leftarrow i}$ denotes a time trend for the industry $j$ to which patent class $i$ belongs: $;^{16} t \beta_{c}$ denotes a time trend for country $c$. Since other country- or industry-level factors accompanying the changes in dismissal law could lead to

${ }^{16}$ Because there are about 500 patent classes, we estimate the linear industry trends at the patent category level, which encompasses several patent classes. There are six patent categories. 
country-specific as well as industry-specific time trends, these tests enable us to isolate better the pure effect of changes in dismissal law on innovation. The other variables are as defined in equation (1). Since the dismissal law index varies at the country-year level and our innovation proxies are measured at the patent class level, we estimate standard errors that are clustered at the country-year level.

In these tests, apart from creditor rights changes and economic development, we also control for other industry- and country-level variables that may affect innovation. We first account for bilateral trade. Using U.S. patents to proxy innovation in non-U.S. countries avoids concerns of heterogeneity stemming from employing patents filed under each country's patenting system. However, this strategy introduces a potential bias: countries that export to the United States may file more patents with the USPTO, particularly in their exportintensive industries. ${ }^{17}$ To avoid biased estimates, we add as controls the logarithm of the level of imports and the level of exports that a given country has with the United States in each year in each three-digit International Standard Industrial Classification (ISIC) industry. These variables are available from 1978 onward. ${ }^{18}$ We also account for industry-level comparative advantage. A possible determinant of innovation is the comparative advantage that a country possesses in its different industries. As our proxy for industry-level comparative advantage, we employ the ratio of value added in a three-digit ISIC industry in a particular year to the total value added by that country in that year. ${ }^{19}$

The results of these tests are reported in Table 5. We find that the overall effect of dismissal laws on innovation is positive and significant for all three innovation proxies in these tests. Comparing the coefficient magnitudes with those from the country-level tests reported in Table 3, we notice that the effect of dismissal laws on innovation is larger when measured at the industry level than at the country level. The industry-level tests exploit variation in the effect of dismissal laws within industries, while the country-level tests exploit variation in the effect of dismissal laws within countries. The industry-level tests allow the average effect of dismissal laws on innovation to vary across industries, while the country-level tests do not. As hypothesis 2 proposes, dismissal laws should have a larger effect in industries that are more innovation intensive than those that are less innovation intensive. By possibly reflecting large effects in the innovation-intensive industries, the resulting large coefficient estimates in Table 5

\footnotetext{
${ }^{17}$ MacGarvie (2006) finds that citations to a country's patents are correlated with the level of exports and imports that the country has with the United States.

${ }^{18}$ The data are from Nicita and Olarreaga (2007). We match the patent classes to the three-digit International Standard Industrial Classification (ISIC), using a two-step procedure. First, the updated National Bureau of Economic Research (NBER) patent data set assigns each patent to a two-digit standard industrial classification (SIC). We then employed the concordance from two-digit SIC to three-digit ISIC codes. Since every patent is already assigned to a patent class in the original NBER patent data set, this completes our match from the patent class to the three-digit ISIC code.

${ }^{19}$ Data for these measures are from the 2006 release of the United Nations Industrial Development Organization's Industrial Statistics Database INDSTAT3, Revision 2.
} 


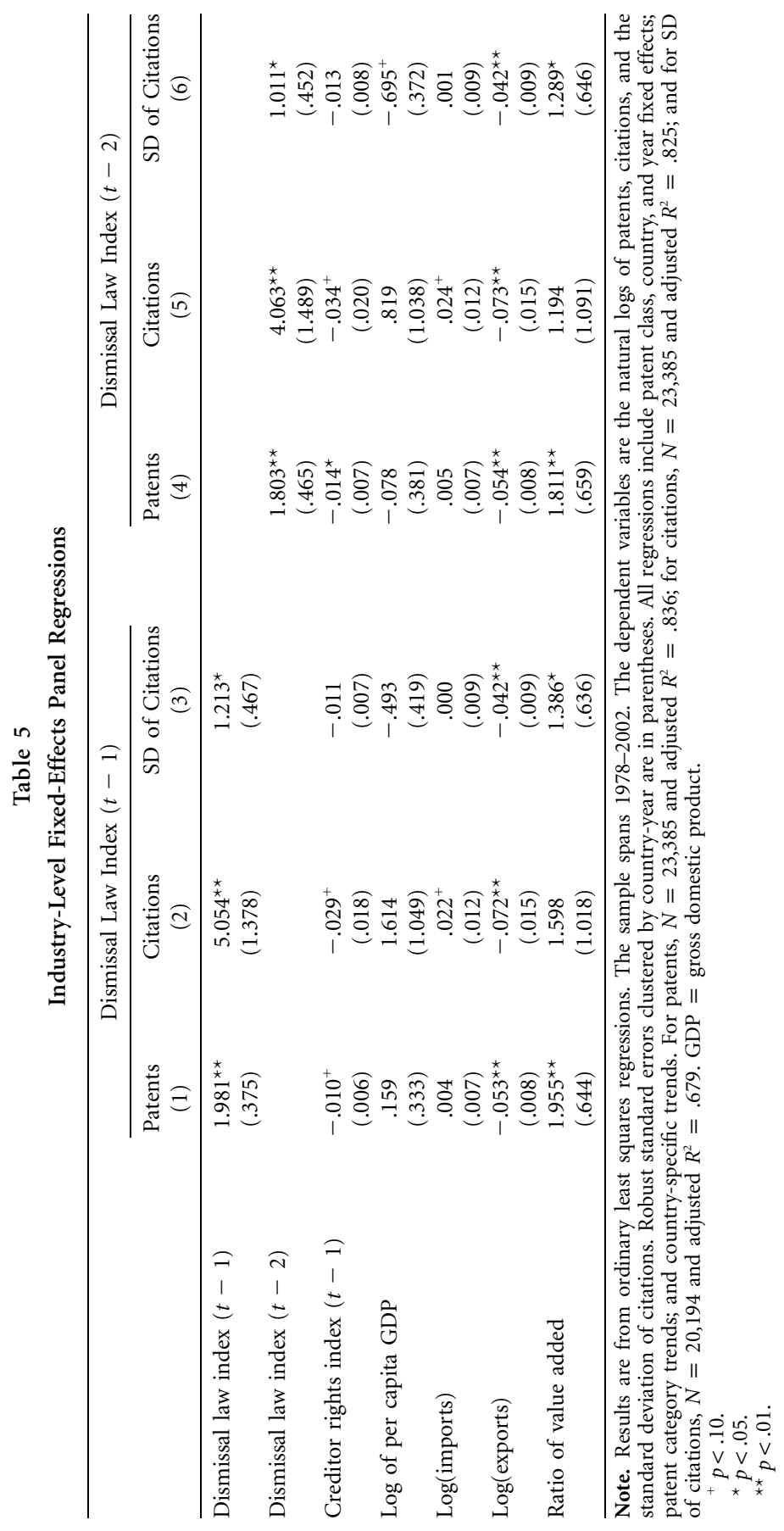

This content downloaded from 202.174.120.162 on June 08, 2019 06:50:15 AM All use subject to University of Chicago Press Terms and Conditions (http://www.journals.uchicago.edu/t-and-c). 
suggest that the results from the industry-level tests are consistent with hypothesis 2. We test hypothesis 2 more extensively in Section 6.5.

Using coefficient estimates from columns 1-3 of Table 5, we find that the law change relating to procedural constraints on dismissal in the United Kingdom in 1987 corresponds to an increase in annual number of patents, number of citations, and standard deviation of citations by 7.8 percent, 21.1 percent, and 4.7 percent, respectively.

\subsection{Addressing Identification Concerns}

Despite the fixed effects and country- and industry-specific time trends, we cannot necessarily attribute a causal interpretation to the observed relationship between dismissal laws and innovation, since residual unobserved factors accompanying law changes may lead to this correlation.

First, to cater to their political constituencies, more left-leaning governments may be inclined to strengthen labor laws (see, for example, Botero et al. 2004; Deakin, Lele, and Siems 2007). Leftist governments may also be more likely to invest in education and other public services, which may have a positive impact on innovation in a given country. Therefore, other factors coinciding with changes in government may hinder identification. Second, changes in dismissal law may be also correlated with GDP growth (business cycles) in a country. On the one hand, lower levels of economic growth (that is, contractions in the business cycle) may encourage the adoption of more stringent dismissal laws. On the other hand, innovation should foster economic growth, as suggested by the endogenous-growth theory (Aghion and Howitt 1992). Thus, any effect of economic growth and/or business cycles on dismissal laws could hinder the identification as well.

We now address the concerns stemming from these sources of endogeneity. First, we directly control for the effect of changes in a country's government by employing a time-varying proxy for the political leanings of a country's government: the variable Government captures the balance of power between leftand right-leaning parties in a given country's parliament. This variable takes on values from 1 to 5, with 1 denoting a hegemony of right-wing (and center) parties and 5 denoting a hegemony of social-democratic and other left-wing parties. ${ }^{20}$ More left-leaning governments indeed tend to pass stricter dismissal laws: numerically, the variable Government is positively correlated with the dismissal law index (the correlation is .49). Second, we also include GDP growth (data from Penn World Table [Heston, Summers, and Aten 2009]) and countryspecific indicators for periods of business cycle contractions (as defined by the Economic Cycle Research Institute). ${ }^{21}$ We report the results in Table 6. Columns

\footnotetext{
${ }^{20}$ This variable is from Armingeon et al. (2008), who collected annual political and institutional data for 23 democratic countries from 1960 to 2006. Our variable Government is called "govparty" by Armingeon et al. (2008).

${ }^{21}$ For business cycle dates, see Economic Cycle Research Institute, International Business Cycle Dates (http://www.businesscycle.com/ecri-business-cycles/international-business-cycle-dates-chronologies).
} 


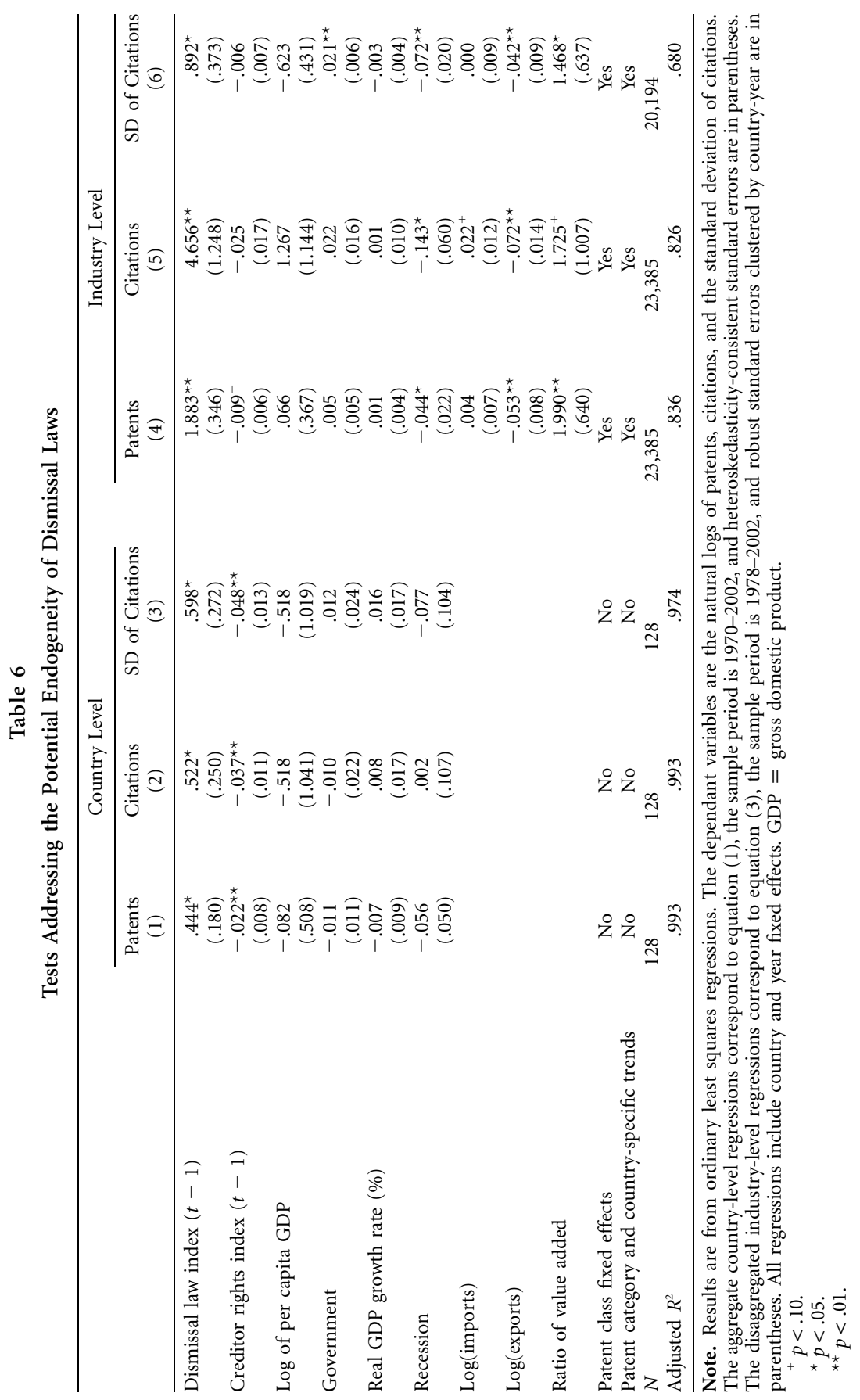

This content downloaded from 202.174.120.162 on June 08, 2019 06:50:15 AM All use subject to University of Chicago Press Terms and Conditions (http://www.journals.uchicago.edu/t-and-c). 
1-3 focus on the aggregate country-level sample corresponding to equation (1), while columns 4-6 employ the disaggregated industry-level sample corresponding to equation (3). ${ }^{22}$

We find that the political persuasion of a country's government is not significantly associated with our proxies for innovation in most specifications. Furthermore, innovation is negatively correlated with times of business cycle contractions, although these correlations are significant only in the specifications from the industry-level sample (columns 4-6). Crucially, however, we observe that the coefficient on the dismissal law index remains positive and significant in all instances. Comparing the coefficients with and without controlling for these sources of endogeneity (Table 6, columns 1-3, versus Table 3; Table 6, columns 4-6, versus Table 5) shows that accounting for the possible endogeneity of changes in dismissal law does not materially affect the economic magnitude of the documented effect.

\subsection{Triple-Difference Tests Controlling for All Country-Level Variation}

The previous tests account for important sources of endogeneity. However, the concern remains that some unobservable time-varying country-level omitted variables that are correlated with changes in dismissal laws may confound our results. To address these endogeneity concerns, we conduct a test where we include country $\times$ year fixed effects. These fixed effects absorb all variation at the country-year level, which allows us to account for all sources of omitted variables for each country and year combination in our sample. The identification strategy is motivated by hypothesis 2 , in which we argue that the effect of dismissal laws should be disproportionately stronger in industries that exhibit a greater propensity to innovate than in other industries.

We measure an industry's propensity to innovate using two proxies. First, we proxy innovation intensity using the National Science Foundation's measure of the number of R\&D scientists and engineers employed per thousand employees in a (manufacturing) industry in the United States. ${ }^{23}$ The second measure employs firm-level data for the United States and proxies innovation intensity as

\footnotetext{
${ }^{22}$ In Table 6 and subsequent tests, we report only results using the first lag of the dismissal law index to save space.

${ }^{23}$ The data for this innovation-intensity measure are taken from National Science Foundation (1996, table A-54). For each of the two-digit SIC manufacturing industries, we calculate the average number of scientists employed over the 1983-93 period. To match the SIC industries to patent classes, we use the assignment of SIC codes for each patent from the NBER patent file. In particular, for all countries available in the NBER patent file, we determine for each patent class the SIC to which most patents were assigned over the 1970-2002 period; that SIC is used as the representative SIC for that patent class. This innovation-intensity measure is available for 15 two-digit SIC manufacturing industries, or 245 patent classes in our sample; as we use the time-series average of the number of scientists employed, this measure does not have any time-series variation.
} 
the median of R\&D/Assets per industry and year. ${ }^{24}$ Since the United States remains the front-runner in innovation, these U.S.-based measures come close to the efficient level of innovative intensity for any industry. Furthermore, given technological commonalities, an industry that is innovation intensive in the United States is likely to be so in another country too, which enables us to proxy innovation intensity for a particular non-U.S. industry using the U.S. measure as well.

In this test, we interact the dismissal law index with the innovation intensity of an industry:

$$
\begin{aligned}
y_{i c t}= & \beta_{c, t}+t \beta_{j \leftarrow i}+\beta_{i} \\
& +\beta_{1} \times\left(\text { DismissalLaws }_{c, t-1} \times{\text { InnovationIntensity } \left.y_{i, t}^{\mathrm{US}}\right)}\right. \\
& +\beta_{2} \times \text { InnovationIntensity }_{i, t}^{\mathrm{US}}+\beta \boldsymbol{X}_{i c t}+\varepsilon_{i c t} .
\end{aligned}
$$

The country $\times$ year fixed effects $\left(\beta_{c, t}\right)$ allow us to control for all observed and unobserved variables at the country-year level. These fixed effects subsume the direct effect of dismissal laws. Note that the interaction term (DismissalLaws ( $_{c, t-1}$ $\times$ InnovationIntensity $y_{i, t}^{\mathrm{US}}$ ) varies at the level of industry $i$ in country $c$ in application year $t$. Since our dependent variable, $y_{i c t}$, exhibits equivalent variability, the coefficient of interest $\beta_{1}$ is identified in the presence of country $\times$ year fixed effects. The term $\beta_{1}$ measures the relative effect of dismissal laws across industries that vary in their innovation intensity; hypothesis 2 predicts that $\beta_{1}>0$.

The results of this triple-difference test are reported in Table 7 . When the average number of $R \& D$ scientists and engineers per industry is used as our innovation-intensity proxy, $\beta_{2}$ from equation (4) is not identified, as the measure does not exhibit time-series variation. The term $\beta_{2}$ is identified when lagged median of R\&D/Assets per industry and year is used to proxy for innovation intensity, as that measure exhibits time-series variation. In all instances, the coefficient of the interaction term $\beta_{1}$ is positive and statistically significant, indicating that the positive impact of dismissal laws on innovation is significantly more pronounced in innovation-intensive industries.

In this setting, the direct effect of dismissal laws is subsumed in the country $x$ year fixed effects, and the coefficient $\beta_{1}$ captures the magnitude of the second derivative $\partial^{2} y_{i c t} / \partial$ DismissalLaws $\partial$ InnovationIntensity. We therefore evaluate economic magnitudes by comparing the marginal effect of dismissal laws $\partial y_{i c t} / \partial$ DismissalLaws between a high-innovation-intensive industry (for example, the ninetieth percentile of InnovationIntensity) and a low-innovation-intensive industry (for example, the tenth percentile of InnovationIntensity). The ninetieth

\footnotetext{
${ }^{24}$ For all firms headquartered in the United States, we calculate the ratio of R\&D expenses to total assets (R\&D/Assets) using Compustat North America data; missing observations for R\&D are replaced by zero. This ratio is winsorized at the ninety-ninth percentile. We then calculate the median of $\mathrm{R} \& \mathrm{D} /$ Assets per two-digit SIC industry and year, take the lagged value, and match the SIC industries to NBER patent classes using the matching procedure described previously. This measure is available for 446 patent classes in our sample and exhibits time-series variation.
} 


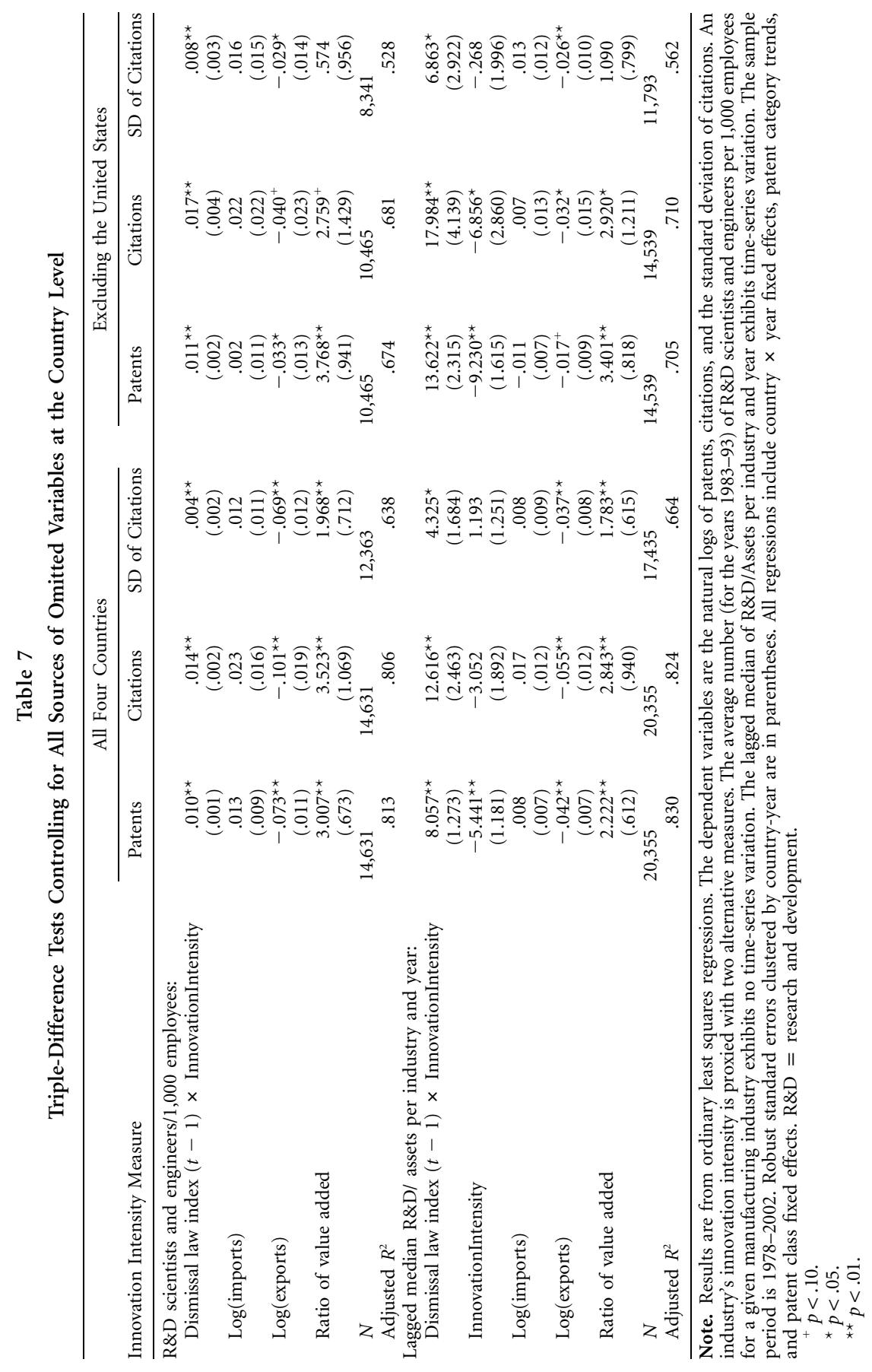

This content downloaded from 202.174.120.162 on June 08, 2019 06:50:15 AM All use subject to University of Chicago Press Terms and Conditions (http://www.journals.uchicago.edu/t-and-c). 
and tenth percentile values of the number of $\mathrm{R} \& \mathrm{D}$ scientists and engineers are 62.7 and 6.5, respectively. On the basis of the results in columns 1-3 of Table 7 , when the measure of innovation intensity is the average number of R\&D scientists and engineers, we estimate that the effect of dismissal laws on innovation in the high-innovation-intensive industries is greater than the effect in the low-innovation-intensive industries by 75.4 percent, 119.6 percent, and 25.2 percent for the number of patents, number of citations, and standard deviation of citations, respectively.

\subsection{Triple-Difference Tests Accounting for Industry-Level Placebo Effects}

Next, we further alleviate endogeneity concerns stemming from time-varying omitted variables at the country and industry level by identifying a control group of innovating entities that would be affected by such omitted variables but should be unaffected by changes in dismissal law. As highlighted in our theoretical motivation, the hypothesized effect of dismissal laws on innovation stems from the increased dismissal protection for firm employees. Changes in dismissal law should not have an impact on individual inventors, who are not employed by a firm. Therefore, they provide a relevant control group to net out possible placebo effects. On the basis of this intuition, we conduct the following tripledifference test, in which we examine the effect of dismissal laws on innovation by firms minus the innovation generated by stand-alone inventors:

$$
\begin{aligned}
\ln \left(y_{i c t, \text { firms }}-y_{i c t, \text { individuals }}\right)= & t \beta_{j \leftarrow i}+t \beta_{c}+\beta_{i}+\beta_{c}+\beta_{t} \\
& +\beta_{1} \times \text { DismissalLaws }_{c, t-1}+\beta \boldsymbol{X}_{i c t}+\varepsilon_{i c t},
\end{aligned}
$$

where $y_{i c t \text {,firms }}$ and $y_{i c t \text {,individuals }}$ represent measures of innovation by firms and individuals in a patent class $i$, country $c$, and year $t .^{25}$ The set of control variables is denoted $\boldsymbol{X}_{i c t}$, and $t \beta_{j \leftarrow i}$ and $t \beta_{c}$ denote trends at the industry and country level, respectively. These triple-difference tests enable us to control for any omitted country- or industry-level variable that affects the passage of dismissal laws and affects innovation performed by all agents in the economy. In Table 8, we find the coefficient $\beta_{1}$ to be positive and statistically as well as economically significant.

We can conclude with a reasonable degree of certainty that, within countries, more stringent dismissal laws did indeed foster innovation and that our results are not affected by endogeneity stemming from other country- or industry-level confounding factors that may have coincided with the changes in dismissal law.

\subsection{Effect of Other Dimensions of Labor Laws}

Next, we test our hypothesis 3 that dimensions of labor laws other than those that affect the ex post likelihood of an employee being dismissed from employment do not have a positive effect on innovation. For this purpose, we contrast

\footnotetext{
${ }^{25}$ As individual-specific identifiers are not available in the patent data set (as opposed to firmspecific identifiers), we cannot construct a measure for the standard deviation of citations for individual inventors.
} 
Table 8

Triple-Difference Tests Accounting for Industry-Level Placebo Effects

\begin{tabular}{lcc}
\hline & $\begin{array}{c}\text { Patents } \\
(1)\end{array}$ & $\begin{array}{c}\text { Citations } \\
(2)\end{array}$ \\
\hline Dismissal law index $(t-1)$ & $.824^{\star *}$ & $2.583^{\star *}$ \\
& $(.226)$ & $(.824)$ \\
Creditor rights index $(t-1)$ & $-.012^{\star}$ & -.013 \\
& $(.005)$ & $(.011)$ \\
Log of per capita GDP & -.131 & $2.037^{\star *}$ \\
& $(.243)$ & $(.704)$ \\
Log(imports) & -.011 & -.012 \\
& $(.007)$ & $(.013)$ \\
Log(exports) & $-.052^{\star *}$ & $-.055^{\star *}$ \\
& $(.009)$ & $(.015)$ \\
Ratio of value added & $2.723^{\star *}$ & $3.243^{\star *}$ \\
& $(.588)$ & $(.936)$ \\
\hline
\end{tabular}

Note. Results are from ordinary least squares regressions. The dependent variable is the natural log of the difference between innovation by firms and innovation by individuals. The sample period is 1978-2002. Robust standard errors clustered by country-year are in parentheses. $N=23,385$. Adjusted $R^{2}=.735$ for patents and .641 for citations. All regressions include patent class, country, and year fixed effects; patent category trends; and country-specific trends. GDP = gross domestic product.

${ }^{*} p<.05$.

${ }_{* *}^{*} p<.01$.

the effect of dismissal laws with other dimensions of labor regulation. Deakin, Lele, and Siems (2007) analyze 40 different dimensions of labor and employment law and group them into five categories, each represented by a longitudinal labor law (sub)index: the regulation of alternative forms of labor contracting (for example, self-employment, part-time work, and contract work), regulation of working time, regulation of dismissal (our dismissal law index), employee representation, and rules governing industrial action. ${ }^{26}$

We estimate the following regression model:

$$
\begin{aligned}
y_{i c t}= & t \beta_{j \leftarrow i}+t \beta_{c}+\beta_{i}+\beta_{c}+\beta_{t}+\beta_{1} \times 1 \mathrm{~A}_{c, t-1}+\beta_{2} \times \mathrm{lB}_{c, t-1} \\
& +\beta_{3} \times 1 \mathrm{C}_{c, t-1}+\beta_{4} \times \mathrm{lD}_{c, t-1}+\beta_{5} \times \mathrm{lE}_{c, t-1}+\beta X_{i c t}+\varepsilon_{i c t}
\end{aligned}
$$

where $\beta_{1}-\beta_{5}$ measure the impact on measures of innovation of the respective labor law for the five components of the Deakin, Lele, and Siems (2007) labor law index: alternative employment contracts $\left(\mathrm{lA}_{c, t-1}\right)$, regulation of working time $\left(\mathrm{lB}_{c, t-1}\right)$, regulation of dismissal $\left(\mathrm{lC}_{c, t-1}\right)$, employee representation $\left(\mathrm{lD}_{c, t-1}\right)$, and industrial action $\left(\mathrm{IE}_{c, t-1}\right)$. The other variables are as defined for equation (3).

Table 9 presents results of these tests. The only dimension of labor laws has

${ }^{26}$ While the correlation between different labor law components is positive and significant, we do not encounter any multicollinearity problems with the tests. 
Table 9

Effect of Dismissal Laws vis-à-vis Other Dimensions of Labor Laws

\begin{tabular}{lccc}
\hline & Patents & Citations & SD of Citations \\
\hline Dismissal law index $(t-1)$ & $2.030^{\star *}$ & $4.971^{\star *}$ & $1.204^{\star *}$ \\
Regulation of working time $(t-1)$ & $.380)$ & $(1.213)$ & $(.431)$ \\
& -.264 & $2.228^{\star *}$ & $1.069^{\star *}$ \\
Alternative employment contracts $(t-1)$ & $(.276)$ & $(.786)$ & $(.305)$ \\
& $-.222^{+}$ & .048 & .049 \\
Employee representation $(t-1)$ & $(.125)$ & $(.322)$ & $(.149)$ \\
& .264 & $-2.708^{\star *}$ & $-1.126^{\star *}$ \\
Industrial action $(t-1)$ & $(.331)$ & $(.959)$ & $(.384)$ \\
& .327 & 1.262 & .051 \\
Creditor rights index $(t-1)$ & $(.427)$ & $(1.368)$ & $(.406)$ \\
& -.009 & $-.037^{\star}$ & $-.014^{\star}$ \\
Log of per capita GDP & $(.006)$ & $(.016)$ & $(.006)$ \\
Log(imports) & .248 & 1.711 & -.535 \\
Log(exports) & $(.341)$ & $(1.061)$ & $(.381)$ \\
Ratio of value added & .004 & .016 & -.003 \\
& $(.007)$ & $(.012)$ & $(.009)$ \\
$N$ & $-.053^{\star *}$ & $-.070^{\star *}$ & $-.040^{\star *}$ \\
Adjusted $R^{2}$ & $(.008)$ & $(.014)$ & $(.009)$ \\
\hline Note Results & $1.987^{\star *}$ & $1.958^{+}$ & $1.512^{\star}$
\end{tabular}

Note. Results are from ordinary least squares regressions. The sample period is 1978-2002. The dependent variables are the natural logs of patents, citations, and the standard deviation of citations. Robust standard errors clustered by country-year are in parentheses. All regressions include patent class, country, and year fixed effects; patent category trends; and country-specific trends. GDP = gross domestic product.

${ }^{+} p<.10$.

${ }^{*} p<.05$.

$* * p<.01$.

a consistently positive and significant impact on innovation is the regulationof-dismissal component.

\subsection{Physical Capital Deepening?}

The positive effects of dismissal laws on innovation documented in this paper, instead of being an outcome of better incentives to innovate, could be alternatively due to firms' efforts to save on labor costs by shifting to less laborintensive and more innovative, capital-intensive technologies. If this were indeed the case, we should observe an increase in capital-and/or R\&D—expenditures after the strengthening of dismissal laws. To test this, we use detailed data on firm-level R\&D expenditure and CAPEX from Compustat Global. The sample for these tests spans 1989 (first year of available the Compustat Global data) to 2006 (last year of the Deakin, Lele, and Siems [2007] labor law index coding). For these tests, we remove financial institutions (standard industrial classification [SIC] 6000-6999), utilities (SIC 4900-4999), and governmental and quasigovernmental enterprises (SIC 9000 and above) from the sample. In addition to 
the time-varying control variables from Table 9, we control for leverage (Debt/ Assets), profitability (RoA), the asset market-to-book ratio (Market-to-Book), and firm size (ln[Market Equity]). ${ }^{27}$ Summary statistics for the dependent variables are reported in Table 2.

We implement the regression model

$$
\begin{aligned}
y_{f c t}= & \beta_{f}+\beta_{t}+\beta_{1} \times 1 \mathrm{~A}_{c, t-1}+\beta_{2} \times 1 \mathrm{~B}_{c, t-1}+\beta_{3} \times 1 \mathrm{C}_{c, t-1} \\
& +\beta_{4} \times 1 \mathrm{D}_{c, t-1}+\beta_{5} \times 1 \mathrm{E}_{c, t-1}+\beta X_{f c t}+\varepsilon_{f c t}
\end{aligned}
$$

where $y_{f c t}$ is R\&D/Assets or, in an alternative specification, CAPEX/Assets; both are measured at the firm level. Firm and year fixed effects are denoted $\beta_{f}$ and $\beta_{t}$, respectively, while $\beta_{1}-\beta_{5}$ measure the impact on investment of the respective labor law for the five components of the Deakin, Lele, and Siems (2007) labor law index, as in equation (6). The set of control variables is denoted $\boldsymbol{X}_{f c t}$.

We present the results in Table 10. According to the results, there is no evidence of stricter dismissal laws leading to capital deepening as measured by CAPEX or R\&D expenditures.

\section{Conclusion}

We have shown that innovation is causally determined by laws governing the ease with which firms can dismiss their employees. We provided this evidence using patents and citations as proxies for innovation and changes in dismissal laws across countries. Since the outcomes of innovation are unpredictable, they are difficult to contract ex ante (Aghion and Tirole 1994), which renders private contracts to motivate innovation susceptible to renegotiation. Such possibility of renegotiating contracts dilutes their ex ante incentive effects. Since laws are considerably more difficult for private parties to alter than firm-level contracts, legal protection of employees in the form of stringent dismissal laws can introduce the time consistency in firm behavior that is absent with only private contracting. Because endogenous-growth theory (Aghion and Howitt 1992) posits that firm-level innovation fosters country-level economic growth, assessing the aggregate welfare implications of labor laws is an important topic for future research. Our study highlights one important positive effect of dismissal laws,

\footnotetext{
${ }^{27}$ The variable $\mathrm{R} \& \mathrm{D} /$ Assets is the ratio of $\mathrm{R} \& \mathrm{D}$ expense to total assets; missing $\mathrm{R} \& \mathrm{D}$ observations are set to zero. The variable CAPEX/Assets is the ratio of capital expenditures to total assets; Debt/ Assets is the ratio of total interest-bearing debt to assets. The variable RoA is the ratio of earnings before interest, taxes, depreciation, and amortization to total assets. The variable Market-to-Book is the market value of assets divided by the book value of assets, where the market value of assets is the book value of assets plus the market value of common equity less the sum of the book value of common equity and balance-sheet-deferred taxes. The log of the market value of equity (in millions of U.S. dollars) is $\ln$ (Market Equity). We winsorize all firm-level variables at the ninety-ninth percentile; RoA, Market-to-Book, and $\ln$ (Market Equity) are additionally winsorized at the first percentile.
} 
Table 10

Dismissal Laws and Capital Deepening

\begin{tabular}{|c|c|c|c|c|}
\hline & \multicolumn{2}{|c|}{$\mathrm{R} \& \mathrm{D} /$ Assets } & \multicolumn{2}{|c|}{ CAPEX/Assets } \\
\hline & (1) & (2) & (3) & (4) \\
\hline Dismissal law index $(t-1)$ & $\begin{array}{c}.006 \\
(.016)\end{array}$ & $\begin{array}{c}-.005 \\
(.013)\end{array}$ & $\begin{array}{l}.016 \\
(.035)\end{array}$ & $\begin{array}{l}.005 \\
(.037)\end{array}$ \\
\hline Regulation of working time $(t-1)$ & & $\begin{array}{c}.008 \\
(.015)\end{array}$ & & $\begin{array}{c}.036^{+} \\
(.020)\end{array}$ \\
\hline Alternative employment contracts $(t-1)$ & & $\begin{array}{l}.024 \\
(.016)\end{array}$ & & $\begin{array}{r}-.018 \\
(.013)\end{array}$ \\
\hline Employee representation $(t-1)$ & & $\begin{array}{c}.026 \\
(.027)\end{array}$ & & $\begin{array}{c}-.004 \\
(.028)\end{array}$ \\
\hline Industrial action $(t-1)$ & & $\begin{array}{c}-.022 \\
(.021)\end{array}$ & & $\begin{array}{r}-.018 \\
(.025)\end{array}$ \\
\hline Creditor rights index $(t-1)$ & $\begin{array}{c}.001 \\
(.001)\end{array}$ & $\begin{array}{c}.002^{\star} \\
(.001)\end{array}$ & $\begin{array}{c}.003 \\
(.002)\end{array}$ & $\begin{array}{c}.005^{*} \\
(.002)\end{array}$ \\
\hline Log of per capita GDP & $\begin{array}{c}.031 \\
(.029)\end{array}$ & $\begin{array}{c}-.022 \\
(.020)\end{array}$ & $\begin{array}{l}.090^{\star *} \\
(.025)\end{array}$ & $\begin{array}{l}.110^{* \star} \\
(.039)\end{array}$ \\
\hline Debt/Assets & $\begin{array}{r}-.005^{\star} \\
(.002)\end{array}$ & $\begin{array}{r}-.005^{\star} \\
(.002)\end{array}$ & $\begin{array}{c}-.001 \\
(.001)\end{array}$ & $\begin{array}{c}-.001 \\
(.001)\end{array}$ \\
\hline RoA & $\begin{array}{c}-.101^{* *} \\
(.005)\end{array}$ & $\begin{array}{c}-.101^{\star *} \\
(.005)\end{array}$ & $\begin{array}{c}-.016^{* *} \\
(.002)\end{array}$ & $\begin{array}{c}-.016^{* *} \\
(.002)\end{array}$ \\
\hline Market-to-Book & $\begin{array}{l}.000 \\
(.000)\end{array}$ & $\begin{array}{l}.000 \\
(.000)\end{array}$ & $\begin{array}{c}-.000 \\
(.000)\end{array}$ & $\begin{array}{r}-.000 \\
(.000)\end{array}$ \\
\hline $\ln$ (Market Equity) & $\begin{array}{c}-.003^{* *} \\
(.001)\end{array}$ & $\begin{array}{c}-.003^{\star *} \\
(.001)\end{array}$ & $\begin{array}{l}.007^{\star *} \\
(.001)\end{array}$ & $\begin{array}{c}.007^{\star *} \\
(.001)\end{array}$ \\
\hline$N$ & 110,908 & 110,908 & 105,221 & 105,221 \\
\hline Adjusted $R^{2}$ & .734 & .734 & .504 & .504 \\
\hline
\end{tabular}

Note. Results are from ordinary least squares regressions. The sample period is 1989-2006. Robust standard errors clustered by country-year are in parentheses. GDP = gross domestic product; RoA = ratio of earnings before interest, taxes, depreciation, and amortization to total assets. All regressions include firm and year fixed effects.

$+p<.10$.

$* p<.05$.

${ }^{* *} p<.01$.

namely, their ability to spur innovation, that must be factored into such an assessment.

\section{Appendix}

\section{Components of the Dismissal Law Index}

The dismissal law index is one of the five labor law subindices constructed by Deakin, Lele, and Siems (2007). The components of the other subindices (alternative employment contracts, regulation of working time, employee representation, and industrial action) can also be found in Deakin, Lele, and Siems (2007). The dismissal law subindex of the labor law index measures the extent to which the regulation of dismissal favors the employee. The subindex is an average score of the following nine variables (the information in Table A1 is from Deakin, Lele, and Siems [2007]). 
Table A1

Components of the Dismissal Law Index

\begin{tabular}{|c|c|}
\hline Variable & Description \\
\hline $\begin{array}{l}\text { Legally mandated notice } \\
\text { period (for all dismissals) }\end{array}$ & $\begin{array}{l}\text { Measures in weeks the length of notice that has to be given to a } \\
\text { worker with } 3 \text { years' employment; the scores are normalized so } \\
\text { that } 0 \text { weeks }=0 \text { and } 12 \text { weeks }=1\end{array}$ \\
\hline $\begin{array}{l}\text { Legally mandated } \\
\text { redundancy compensation }\end{array}$ & $\begin{array}{l}\text { Measures the amount of redundancy compensation payable to a } \\
\text { worker made redundant after } 3 \text { years' employment, measured in } \\
\text { weeks of pay; the scores are normalized so that } 0 \text { weeks }=0 \\
\text { and } 12 \text { weeks }=1\end{array}$ \\
\hline $\begin{array}{l}\text { Minimum qualifying period } \\
\text { of service for a normal } \\
\text { case of unjust dismissal }\end{array}$ & $\begin{array}{l}\text { Measures the period of service required for a worker to qualify for } \\
\text { general protection against unjust dismissal; the scores are } \\
\text { normalized so that } 3 \text { years or more }=0 \text { and } 0 \text { months }=1\end{array}$ \\
\hline $\begin{array}{l}\text { Law imposes procedural } \\
\text { constraints on dismissal }\end{array}$ & $\begin{array}{l}\text { Equals } 1 \text { if a dismissal is necessarily unjust if the employer fails to } \\
\text { follow procedural requirements prior to dismissal; equals } .67 \text { if } \\
\text { failure to follow procedural requirements normally leads to a } \\
\text { finding of unjust dismissal; equals . } 33 \text { if failure to follow } \\
\text { procedural requirement is but one of the factors taken into } \\
\text { account in unjust dismissal cases; equals } 0 \text { if there are no } \\
\text { procedural requirements for dismissal; further gradations } \\
\text { between } 0 \text { and } 1 \text { reflect changes in the strength of the law }\end{array}$ \\
\hline $\begin{array}{l}\text { Law imposes substantive } \\
\text { constraints on dismissal }\end{array}$ & $\begin{array}{l}\text { Equals } 1 \text { if dismissal is permissible only for serious misconduct or } \\
\text { fault of the employee; equals } .67 \text { if dismissal is lawful for a } \\
\text { wider range of legitimate reasons (misconduct, lack of capability, } \\
\text { redundancy, and the like); equals } .33 \text { if dismissal is permissible if } \\
\text { it is just or fair, as defined by case law; equals } 0 \text { if employment } \\
\text { is at will (that is, no cause of dismissal is normally permissible); } \\
\text { further gradations between } 0 \text { and } 1 \text { reflect changes in the } \\
\text { strength of the law }\end{array}$ \\
\hline $\begin{array}{l}\text { Reinstatement is normal } \\
\text { remedy for unfair } \\
\text { dismissal }\end{array}$ & $\begin{array}{l}\text { Equals } 1 \text { if reinstatement is the normal remedy for unjust dismissal } \\
\text { and is regularly enforced; equals .67 if reinstatement and } \\
\text { compensation are, de jure and de facto, alternative remedies; } \\
\text { equals } .33 \text { if compensation is the normal remedy; equals } 0 \text { if no } \\
\text { remedy is available as of right; further gradations between } 0 \text { and } \\
1 \text { reflect changes in the strength of the law }\end{array}$ \\
\hline Notification of dismissal & $\begin{array}{l}\text { Equals } 1 \text { if, by law or binding collective agreement, the employer } \\
\text { has to obtain the permission of a state body or third party prior } \\
\text { to an individual dismissal; equals } .67 \text { if a state body or third } \\
\text { party has to be notified prior to the dismissal; equals } .33 \text { if the } \\
\text { employer has to give the worker written reasons for the } \\
\text { dismissal; equals } 0 \text { if an oral statement of dismissal to the } \\
\text { worker suffices; further gradations between } 0 \text { and } 1 \text { reflect } \\
\text { changes in the strength of the law }\end{array}$ \\
\hline Redundancy selection & $\begin{array}{l}\text { Equals } 1 \text { if, by law or binding collective agreement, the employer } \\
\text { must follow priority rules based on seniority, marital status, } \\
\text { number or dependants, and the like, prior to dismissing an } \\
\text { employee for redundancy; equals } 0 \text { otherwise; gradations } \\
\text { between } 0 \text { and } 1 \text { reflect changes in the strength of the law }\end{array}$ \\
\hline Priority in reemployment & $\begin{array}{l}\text { Equals } 1 \text { if, by law or binding collective agreement, the employer } \\
\text { must follow priority rules relating to the reemployment of } \\
\text { former workers; equals } 0 \text { otherwise; gradations between } 0 \text { and } 1 \\
\text { reflect changes in the strength of the law }\end{array}$ \\
\hline
\end{tabular}




\section{References}

Acharya, Viral V., Ramin P. Baghai, and Krishnamurthy V. Subramanian. 2014. Wrongful Discharge Laws and Innovation. Review of Financial Studies 27:301-46.

Acharya, Viral V., and Krishnamurthy V. Subramanian. 2009. Bankruptcy Codes and Innovation. Review of Financial Studies 22:4949-88.

Aghion, Philippe, and Peter Howitt. 1992. A Model of Growth through Creative Destruction. Econometrica 60:323-51.

Aghion, Philippe, and Jean Tirole. 1994. The Management of Innovation. Quarterlv Journal of Economics 109:1185-1209.

Armingeon, Klaus, Marlene Gerber, Philipp Leimgruber, and Michelle Beyeler. 2008. Comparative Political Data Set 1960-2006. Working paper. University of Bern, Institute of Political Science, Bern.

Armour, John, Simon Deakin, Priya Lele, and Mathias M. Siems. 2009. How Do Legal Rules Evolve? Evidence from a Cross-Country Comparison of Shareholder, Creditor and Worker Protection. Working Paper No. 382. University of Cambridge, Centre for Business Research, Cambridge.

Atanassov, Julian, and E. Han Kim. 2009. Labor and Corporate Governance: International Evidence from Restructuring Decisions. Lournal of Finance 64:341-74.

Bagchi, Aditi. 2003. Unions and the Duty of Good Faith in Employment Contracts. Yale Law Journal 112:1881-1910.

Bassanini, Andrea, Luca Nunziata, and Danielle Venn. 2009. Job Protection Legislation and Productivity Growth in OECD Countries. Economic Policy 24:349-402.

Besley, Timothy, and Robin Burgess. 2004. Can Labor Regulation Hinder Economic Performance? Evidence from India. Quarterly Journal of Economics 119:91-134.

Botero, Juan C., Simeon Djankov, Rafael La Porta, Florencio Lopez-de-Silanes, and Andrei Shleifer. 2004. The Regulation of Labor. Quarterly Journal of Economics 119:1339-82.

Chemmanur, Thomas, and Xuan Tian. 2013. Do Anti-takeover Provisions Spur Corporate Innovation? Working paper. Boston College, Carroll School of Management, Chestnut Hill, Mass.

Coolley, Ronald B. 1985. Recent Changes in Employee Ownership Laws: Employers May Not Own Their Inventions and Confidential Information. Business Lawyer 41:57-75.

Deakin, Simon, Priya Lele, and Mathias Siems. 2007. The Evolution of Labour Law: Calibrating and Comparing Regulatory Regimes. International Labour Review 146:13362.

Djankov, Simeon, Caralee McLiesh, and Andrei Shleifer. 2007. Private Credit in 129 Countries. Iournal of Financial Economics 85:299-329.

Ederer, Florian P., and Gustavo Manso. 2013. Is Pay-for-Performance Detrimental to Innovation? Management Science 59:1496-1513.

Garmaise, Mark J. 2011. Ties that Truly Bind: Noncompetition Agreements, Executive Compensation, and Firm Investment. Journal of Law, Economics, and Organization 27: 376-425.

Griliches, Zvi. 1981. Market Value, R\&D, and Patents. Economics Letters 7:183-87.

- 1990. Patent Statistics as Economic Indicators: A Survey. Journal of Economic Literature 28:1661-1707.

Grossman, Gene M., and Elhanan Helpman. 1991. Innovation and Growth in the Global Economy. Cambridge: MIT Press. 
Grossman, Sanford J., and Oliver D. Hart. 1986. The Costs and Benefits of Ownership: A Theory of Vertical and Lateral Integration. Iournal of Political Economy 94:691-719. Hall, Bronwyn H., Adam B. Jaffe, and Manuel Trajtenberg. 2001. The NBER Patent Citations Data File: Lessons, Insights and Methodological Tools. Working Paper No. 8498. National Bureau of Economic Research, Cambridge, Mass.

- 2005. Market Value and Patent Citations. RAND Journal of Economics 36:16-38. Hart, Oliver. 1995. Firms, Contracts, and Financial Structure: Clarendon Lectures in Economics. Oxford: Clarendon Press.

Hart, Oliver, and John Moore. 1990. Property Rights and the Nature of the Firm. Lournal of Political Economy 98:1119-58.

Heston, Alan, Robert Summers, and Bettina Aten. 2009. Penn World Table Version 6.3. University of Pennsylvania, Center for International Comparisons of Production, Income and Prices, Philadelphia.

Imbens, Guido W., and Jeffrey M. Wooldridge. 2009. Recent Developments in the Econometrics of Program Evaluation. Lournal of Economic Literature 47:5-86.

Kaplan, Steven N., and Per Strömberg. 2003. Financial Contracting Theory Meets the Real World: An Empirical Analysis of Venture Capital Contracts. Review of Economic Studies 70:281-315.

Kortum, Samuel, and Josh Lerner. 1999. What Is behind the Recent Surge in Patenting? Research Policy 28:1-22.

Lavetti, Kurt, Carol Simon, and William D. White. 2012. Buying Loyalty: Theory and Evidence from Physicians. Working paper. University of California at Berkeley, Department of Economics, Berkeley.

Lerner, Josh, and Julie Wulf. 2007. Innovation and Incentives: Evidence from Corporate R\&D. Review of Economics and Statistics 89:634-44.

MacGarvie, Megan. 2006. Do Firms Learn from International Trade? Review of Economics and Statistics 88:46-60.

MacLeod, W. Bentley, and Voraprapa Nakavachara. 2007. Can Wrongful Discharge Law Enhance Employment? Economic Journal 117:F218-F278.

Manso, Gustavo. 2011. Motivating Innovation. Journal of Finance 66:1823-60.

McKinsey Global Institute. 1997. Removing Barriers to Growth and Employment in France and Germany. Frankfurt: McKinsey Global Institute.

Menezes-Filho, Naercio, and John Van Reenen. 2003. Unions and Innovation: A Survey of the Theory and Empirical Evidence. Pp. 293-34 in International Handbook of Trade Unions, edited by John T. Addison and Claus Schnabel. Cheltenham: Edward Elgar Publishing.

Narayanan, M. P., and Anant K. Sundaram. 1998. A Safe Landing? Golden Parachutes and Corporate Behavior. Working paper. University of Michigan, Ross School of Business, Ann Arbor.

National Science Foundation. 1996. Research and Development in Industry: 1993. NSF 96304. Arlington, Va.: National Science Foundation. http://www.nsf.gov/statistics/nsf96304.

Neumeyer, Fredrik. 1971. The Employed Inventor in the United States: R\&D Policies, Law and Practice. Cambridge: MIT Press.

Nicita, Alessandro, and Marcelo Olarreaga. 2007. Trade, Production, and Protection Database, 1976-2004. World Bank Economic Review 21:165-71.

Nicoletti, Giuseppe, and Stefano Scarpetta. 2001. Interaction between Product and Labour Market Regulations: Do They Affect Employment? Evidence from the OECD Countries. 
Paper presented at the Banco de Portugal conference Labour Market Institutions and Economic Outcomes, Cascais. June 3-4.

Pakes, Ariel, and Zvi Griliches. 1980. Patents and R\&D at the Firm Level: A First Report. Economics Letters 5:377-81.

Pakes, Ariel, and Mark Schankerman. 1984. The Rate of Obsolescence of Patents, Research Gestation Lags, and the Private Rate of Return to Research Resources. Pp. 73-88 in R\&D, Patents, and Productivity, edited by Zvi Griliches. Chicago: University of Chicago Press.

Reilly, Jim. 2010. Court Documents Detail Infinity Ward's Clash with Activision. IGN News. March 4. http://www.ign.com/articles/2010/03/04/court-documents-detail-infinitywards-clash-with-activision.

Romer, Paul M. 1990. Endogenous Technological Change. Iournal of Political Economy 98:S71-S102.

Saint-Paul, Gilles. 2002a. Employment Protection, International Specialization, and Innovation. European Economic Review 46:375-95.

2002b. The Political Economy of Employment Protection. Lournal of Political Economy 110:672-704.

Tian, Xuan, and Tracy Y. Wang. 2014. Tolerance for Failure and Corporate Innovation. Review of Financial Studies 27:211-55.

Tirole, Jean. 1999. Incomplete Contracts: Where Do We Stand? Econometrica 67:74-81. 